NISTIR 7244

\title{
Initial Evaluation of Displacement Ventilation and Dedicated Outdoor Air Systems for U.S. Commercial Buildings
}

Steven J. Emmerich

Tim McDowell 
NISTIR 7244

\section{Initial Evaluation of Displacement Ventilation and Dedicated Outdoor Air Systems in Commercial Buildings}

Steven J. Emmerich

Building and Fire Research Laboratory

National Institute of Standards and Technology

Tim McDowell

Thermal Energy Simulation Specialists, Inc.

Prepared for:

U.S. Environmental Protection Agency

Washington, DC

July 2005

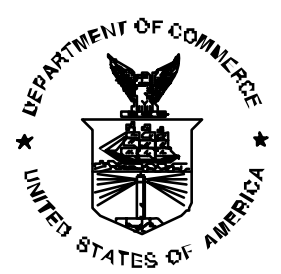

U.S. Department of Commerce Carlos M. Gutierrez, Secretary

Technology Administration

Phillip J. Bond, Undersecretary of Commerce for Technology

National Institute of Standards and Technology William Jeffrey, Director 


\section{ABSTRACT}

Conventional heating, ventilation and air-conditioning (HVAC) systems in commercial buildings meet both outdoor air ventilation and space conditioning requirements using air distribution approaches that provide a mixture of outdoor air and recirculated air with the goal of achieving good air mixing within the occupied space. More recently, advanced ventilation approaches have been proposed, and in some cases installed, that separate the outdoor air ventilation and space conditioning functions (dedicated outdoor air systems or DOAS) or that distribute air to achieve thermal stratification within the space (displacement ventilation or DV). NIST has completed an initial evaluation of the potential benefits and limitations of DV or DOAS in lieu of the conventional mixing ventilation (MV) approach common in U.S. commercial buildings.

The first task in this effort was a compilation of information on DV and DOAS systems. This included a review of the scientific literature from sources including the American Society of Heating, Refrigerating and Air-Conditioning Engineers (ASHRAE), the Air Infiltration and Ventilation Centre (AIVC), and Indoor Air and other international conferences. There is a large body of literature on the design and performance of DV systems including two recent design guides - one published in the U.S. and the other from Europe. As reported in the literature and summarized in the design guides, DV systems have the potential to improve indoor air quality (IAQ) in commercial buildings while also reducing cooling energy use relative to traditional MV systems. However, a close examination of the literature also reveals the need for caution in considering these benefits and care in applying DV systems. Chief among the concerns is that the IAQ improvement is only for some types of contaminants from some types of sources, cooling energy reductions may be offset by heating or fan energy increases, and thermal comfort is not easily achieved and maintained. Despite these concerns, DV systems have promise and are worth pursuing but they have not yet been proven effective in the U.S. applications.

The literature on DOAS contains far fewer detailed studies. Advantages of DOAS cited include improved humidity control, assured delivery of proper ventilation airflow quantities, and reduced energy use. Although one field study of DOAS application in Florida schools supports some of the claimed advantages, the energy and humidity control performance of these systems has not been adequately studied in real buildings.

Since the literature contains more analyses of the performance of DV systems than DOAS, the second task of this effort was a simulation study of the potential energy impacts of DOAS systems in a small U.S. office building. Simulations were performed with a combined airflowbuilding energy modeling tool linking TRNSYS and CONTAM. Based on the simulation results, the DOAS showed promise in reducing energy consumption relative to the baseline system in all climates studied. Also, a more complex DOAS did not show significant improvement over a simpler DOAS consisting of only a preheat coil and enthalpy wheel.

A key outcome of this effort is recommendations for future research and technology transfer efforts based on this initial evaluation. These recommendations include further study of humidity control and other performance aspects of DV systems, field studies of DV and DOAS installations in U.S. commercial buildings, and extension of the U.S. Environmental Protection Agency's modeling tools to include DOAS capability.

Key Words: air distribution, dedicated outdoor air systems, displacement ventilation, energy efficiency, indoor air quality, modeling, outdoor air, ventilation. 


\section{ACKNOWLEDGEMENTS}

This effort was supported by the U.S. Environmental Protection Agency under Interagency Agreement No. DW-13-93973701. The authors express their appreciation to Gregory Brunner and Robert Thompson at EPA and Andrew Persily at NIST for their support and assistance in this work. 



\section{TABLE OF CONTENTS}

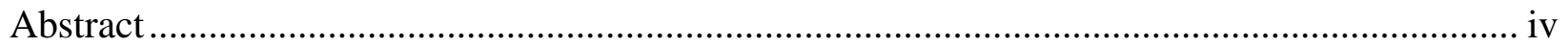

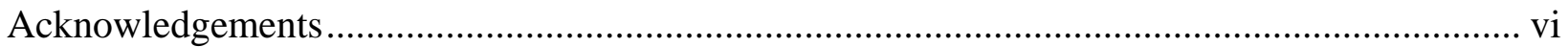

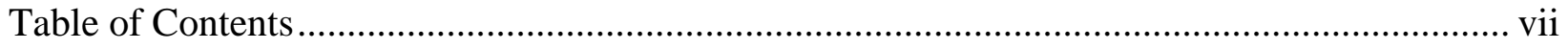

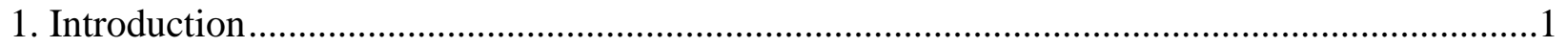

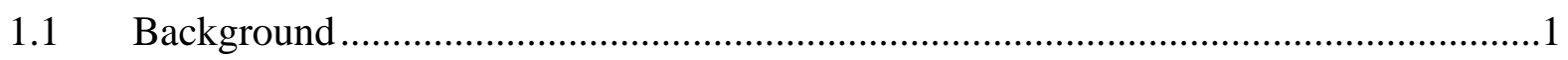

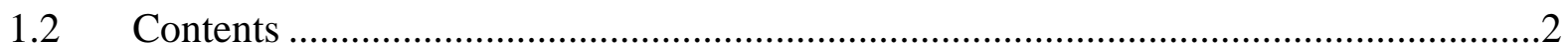

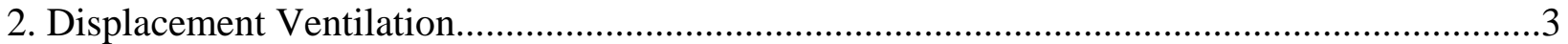

$2.1 \quad$ Review of Displacement Ventilation ...................................................................

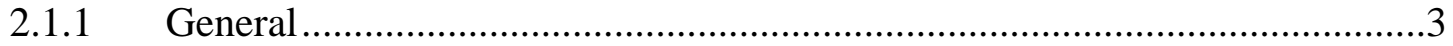

2.1.2 Thermal and Air Quality Performance .......................................................

$2.2 \quad$ Energy and Cost...................................................................................................

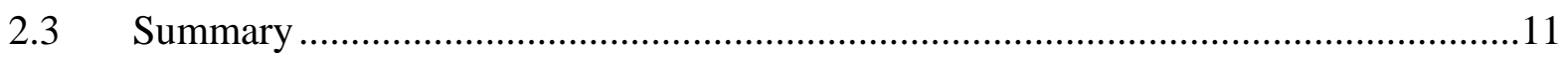

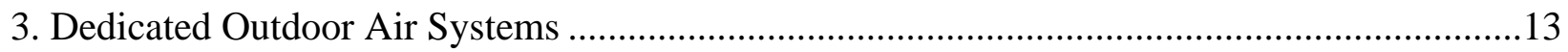

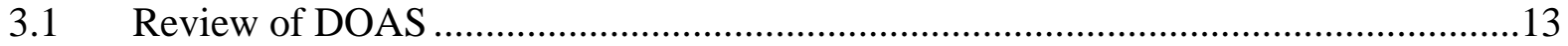

3.1.1 General .....................................................................................13

3.1.2 Energy and Cost ...................................................................................15

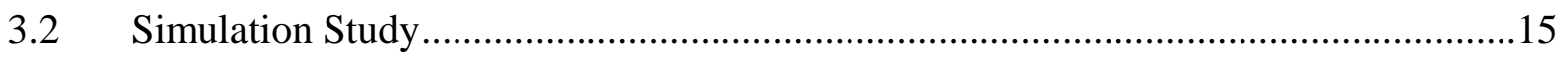

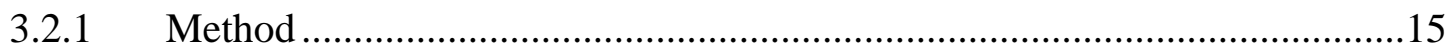

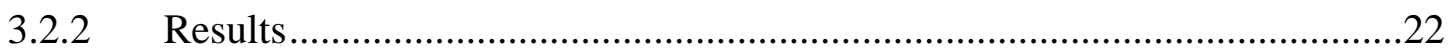

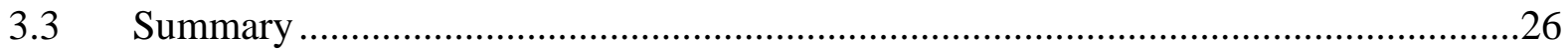

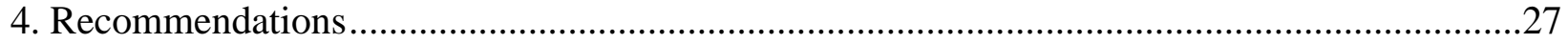

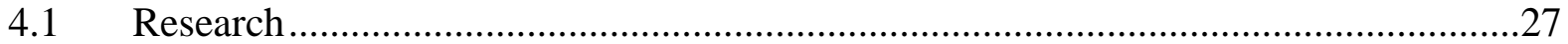

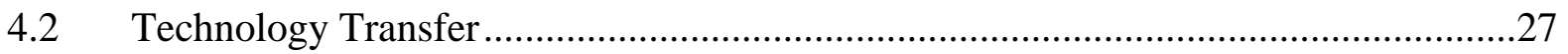

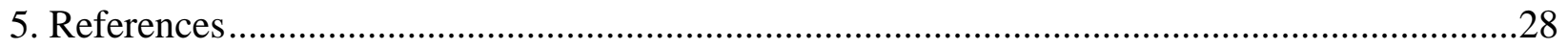




\section{INTRODUCTION}

\subsection{Background}

A number of different approaches to introducing and controlling outdoor air intake and ventilation air distribution have been employed in commercial buildings, with potentially significant impacts on both IAQ and operating costs associated with energy consumption. Typical heating, ventilation and air-conditioning (HVAC) systems in commercial buildings employ equipment intended to simultaneously meet both outdoor air ventilation and space conditioning requirements. These HVAC systems use air distribution approaches that provide a mixture of outdoor air and recirculated air with the goal of achieving good air mixing within the occupied space.. More recently, new ventilation approaches have been proposed and applied that separate the outdoor air ventilation and space conditioning functions (dedicated outdoor air systems or DOAS) or distribute air to provide thermal stratification (displacement ventilation or DV).

The U.S. EPA's Indoor Environment Division (IED) has recently completed a software package that allows building designers and engineers to evaluate the potential financial payback and humidity control benefits of energy recovery ventilation (ERV) systems for school applications (available at http://www.epa.gov/iaq/schooldesign/saves.html). This package includes EFAST (for ERV Financial Assessment Software Tool) which is a simple tool to assist building designers, engineers, ventilation contractors and school officials in deciding whether energy recovery ventilators should be included in the design of new schools (or as a retrofit measure in existing schools) and IHAT (for Indoor Humidity Assessment Tool) which allows the user to model typical school buildings and predict indoor humidity levels with a conventional HVAC system alone and in combination with ERV equipment.

In the first phase of their Advanced Ventilation Systems effort, EPA determined that there are first cost, operating cost, and IAQ advantages to bringing outdoor air into schools using readily available ERV technologies, as compared to the conventional approaches used during most of the latter half of the 20th century. Additional work is needed to determine if there are also first and operating cost and IAQ advantages to using DV or DOAS in lieu of the conventional mixing ventilation method approach in commercial buildings. At the same time, there is also a need to identify any potential limitations of DV and DOAS systems.

The objective of this project is to perform an evaluation of the potential benefits and limitations of these advanced ventilation systems, specifically displacement ventilation and dedicated outdoor air systems, in commercial buildings. A key outcome of this effort is recommendations for future research and technology transfer efforts based on the results of this evaluation.

The first task in this effort was a compilation of information on DV and DOAS systems. This included a review of the scientific literature from sources including the American Society of Heating, Refrigerating and Air-Conditioning Engineers (ASHRAE), the Air Infiltration and Ventilation Centre (AIVC), and Indoor Air conferences and published case study information on actual North American and European applications. As discussed later in this report, the literature review revealed more analyses of the energy impacts of DV systems than DOAS. Therefore, the second task of this effort was a simulation study of the potential energy impacts of DOAS systems for a small U.S. office building. The final task was to develop recommendations for further needed work including potential tool development and more detailed simulations. 


\subsection{Contents}

This report presents an evaluation of displacement ventilation and dedicated outdoor air systems for commercial buildings in the U.S. and is organized into three main sections - Displacement Ventilation, Dedicated Outdoor Systems, and Recommendations. The first section contains an overview of DV and a discussion of potential energy savings based on the literature review. The second section provides an overview of DOAS from the literature review and presents an estimate of the potential energy savings from a simulation study. The third section discusses recommendations including research and technology transfer. 


\section{Displacement Ventilation}

\subsection{Review of Displacement Ventilation}

As the first task in this effort, the published literature on the design, performance, simulation and case studies of displacement ventilation for commercial buildings was reviewed. DV systems may be well suited to applications such as commercial kitchens, industrial spaces, etc. but such applications were outside the scope of this effort. Interest in DV systems has been high recently with dozens of papers published at international ventilation and IAQ conferences such as Indoor Air 2002, Healthy Buildings 2003 and Roomvent 2002 and 2004.

\subsubsection{General}

To avoid confusion, it is necessary to understand what makes an HVAC system a displacement ventilation (DV) system. The ASHRAE Handbook of Fundamentals (HOF) classifies room air diffusion systems as mixing, displacement, unidirectional, and underfloor (ASHRAE 2001). The HOF describes mixing systems as normally discharging conditioned air from outlets near either the ceiling or floor at velocities much greater than those acceptable in the occupied zone to achieve a level of air mixing that creates relatively uniform air velocity, temperature, humidity, and air quality conditions in the occupied zone. Most non-industrial buildings in the U.S. use mixing systems.

In contrast, the HOF describes DV systems as supplying slightly cool air at low velocities directly to the occupied zone from outlets at or near the floor level. The supply air spreads over the floor, forms thermal plumes upon encountering heat sources, and is exhausted by system returns located at or near the ceiling. DV systems purposefully minimize mixing and, in fact, are designed to establish a stable thermal stratification level above the occupied zone such that no mixing occurs between the upper and lower zones. Although not discussed in the HOF, DV systems, as typically applied in Europe, do not employ recirculation of room exhaust air.

Underfloor air distribution (UFAD) systems supply air through a raised floor to local areas typically near building occupants and return air at or near the ceiling. Since both UFAD and DV systems utilize a similar low supply paired with high return pattern, the two are often confused. However, UFAD systems differ from DV systems because they typically supply air at higher velocities such that their higher supply volumes are able to meet larger cooling loads. Depending on the design details of the system and space, UFAD systems may operate as DV systems, however, UFAD systems are outside the scope of this report. McDonnell (2003) recently described UFAD and DV systems with emphasis on key differences. ASHRAE has recently published a detailed guide on UFAD system design that covers topics such as thermal comfort, ventilation effectiveness, energy use, and practical guidance on equipment selection, design, construction, commissioning, operation and maintenance issues (Bauman 2003).

The recently revised ASHRAE Standard 62.1 Ventilation for Acceptable Indoor Air Quality requires use of a zone air distribution effectiveness $\left(E_{z}\right)$ values to be used per equation (1) to determine required minimum zone outdoor airflow $\left(\mathrm{V}_{\mathrm{oz}}\right)$ from required minimum breathing zone outdoor airflow $\left(\mathrm{V}_{\mathrm{bz}}\right)$ depending on the type of air distribution system (ASHRAE 2004).

$$
\mathrm{V}_{\mathrm{oz}}=\mathrm{V}_{\mathrm{bz}} / \mathrm{E}_{\mathrm{z}}
$$

Per Table 6.2 of Standard 62.1-2004, the default value of $E_{z}$ is 1.0 during cooling for mixing systems and for most UFAD systems (specifically, those in which a $0.8 \mathrm{~m} / \mathrm{s}$ jet reaches $1.4 \mathrm{~m}$ above the floor). In contrast, $\mathrm{E}_{\mathrm{z}}$ is 1.2 during cooling for DV systems that achieve unidirectional flow and thermal stratification, thus allowing reduced levels of outdoor air intake. During heating, the default value of $E_{z}$ is 0.7 for both DV and UFAD systems as opposed to 1.0 for most mixing systems. 
Two detailed guides on DV systems have been published recently. The first, Displacement ventilation in non-industrial premises, is a collaborative effort of multiple European authors published by the Federation of European Heating and Air-conditioning Associations (REHVA) and aimed at providing engineers with a comprehensive design manual based on both the practical experience and research from throughout Europe (Skistad et al. 2002). The second, System Performance Evaluation and Design Guidelines for Displacement Ventilation, was published by ASHRAE and is based on a recent ASHRAE research project (Chen and Glicksman 2003). Importantly, the ASHRAE guide addresses differences between U.S. applications of DV systems relative to (typically northern) European applications. These key references and other literature are reviewed in the remainder of this section. Since these two recent publications consider much of the literature prior to their publication, this review is limited to key reports or new information not considered in them.

\subsubsection{Thermal and Air Quality Performance}

The key performance issue for successful DV application is unidirectional flow and the establishment of a stable thermal stratification layer within the zone. As such, many researchers have studied the room airflow, temperature, and contaminant concentration patterns resulting from DV systems through measurements, computational fluid dynamics (CFD), or other modeling approaches.

Chapter 3 of the REHVA guidebook summarizes the basic features of DV performance in nonindustrial applications in terms of room airflow patterns, temperature distribution, contaminant distribution and thermal comfort as informed by the European research and 20 years of practical experience. This chapter describes desirable DV system operation as stratification leading to two stable zones - a cooler, cleaner zone ending at a boundary somewhere above the occupant breathing zone and a warmer, more contaminated zone above the boundary. Plumes from occupants and other heat sources effectively transport both heat and contaminants from the lower zone to the upper zone. The many factors affecting the establishment of such a stratified space include location and strength of both heat and contaminant sources, supply air temperature and airflow rate, room geometry, warm or cool walls and ceilings, and existence of infiltration air. Chapter 4 of the guidebook also discusses the critical topic of draft problems when supplying cool air at or near the floor of occupied spaces. The guidance emphasizes careful diffuser selection to achieve the desired performance.

The literature review in chapter 2 of the ASHRAE guide reviews past research on the same DV performance issues of temperature, airflow, contaminant concentration, comfort, and draft risk. Important conclusions from the ASHRAE literature review include:

- The air temperature near the floor and the vertical temperature gradient in the occupied zone are two of the most important parameters to evaluate in terms of comfort. The floor temperature can be predicted, but past attempts to predict the gradient have proven inadequate.

- The temperature gradient will also affect the flow rate and maximum height of thermal plumes.

- A good diffuser should limit the velocity in the occupied zone and mix the supply air with the surrounding air quickly to reduce risk of draft.

- Contaminant concentration distribution depends on contaminant source type, location, association with heat sources, and room height and may be negatively impacted by cool walls or ceiling. Prediction of contaminant distribution is more difficult than air temperature and airflow distribution. 
- DV systems have generally been considered to be capable of meeting cooling loads of about $40 \mathrm{~W} / \mathrm{m}^{2}$, but may meet somewhat larger loads if higher ceilings or cooled ceilings are used.

- The limited studies on energy and cost of DV systems have indicated that energy consumption and savings will vary significantly with climate, building zone (i.e., core vs. perimeter), and control strategies. DV systems may or may not save energy compared to mixing ventilation (MV).

- Heating for perimeter zones has not been well studied.

The ASHRAE guide also describes new research (ASHRAE RP-949) that addressed the DV system performance issues in the specific context of expected higher cooling loads in U.S. buildings due to both climate and internal gains relative to Northern European buildings. Chen and Glicksman (1999) describe this research in detail including experimental measurements of DV in a test room, validation of a CFD model, CFD predictions of DV performance (in a small office, a large office with internal partitions, a classroom, and a workshop), development of simple models of temperature difference and ventilation effectiveness, and energy and cost analysis. They report good agreement between measured and predicted air velocities and temperatures but greater discrepancies for contaminant concentrations. Simplified models were developed for the vertical temperature distribution and ventilation effectiveness, however, the ventilation effectiveness model only considered occupants as contaminant sources (i.e., associated with heat sources). The ventilation effectiveness model also showed that ventilation effectiveness decreased at lower ventilation rates, with the decrease being very pronounced at sufficiently low ventilation rates. Additionally, the ventilation effectiveness depended on the fraction of the heat load located in the occupied zone of the room. Based on the CFD studies, the authors conclude that properly designed DV systems can maintain thermal comfort while achieving better IAQ than mixing ventilation. Their energy and cost analysis will be discussed later in this report.

Overall, the REHVA and ASHRAE guides (and other past work) tell a positive story on DV performance. However, there are still several potential negatives to consider. First, care must be taken in the design and operation of the system to accommodate both thermal comfort (avoiding drafts and limiting temperature differences) and IAQ. For example, the stratification may be established at a level below the breathing zone of a seated or standing occupant in some areas of the room. This point may be countered by the possible establishment of a local plume around such an occupant that would ensure the occupant is breathing entrained (presumably cleaner) air from below the stratification height. Contaminants from sources not associated with heat generation may not be transported out of the lower zone effectively, as most research has focused on measuring or predicting concentrations of carbon dioxide $\left(\mathrm{CO}_{2}\right)$ or other passive tracer gasses collocated with heat sources. Stable stratification may also not be established due to occupant activity or the distribution of heat sources or sinks. Ventilation effectiveness may be reduced during transient periods such as system start-up. High supply air temperatures and stratification of water vapor in DV rooms may result in unacceptable local humidity conditions in humid climates.

A number of recently published articles have addressed these and other possible concerns. Through both experimental and CFD studies, Bjorn and Nielsen (2002) showed that it is possible for exhaled air to become 'trapped' below the stratification level or to penetrate the breathing zone of another occupant depending on specific conditions in a room and that physical movement in a DV room can cause mixing to increase and even approach the conditions in a MV room at sufficient levels of movement. Similarly, Matsumoto et al. (2004) reported that a moving occupant increased mixing and reduced ventilation effectiveness in a DV space in both experimental and CFD studies. Earlier work by Brohus and Nielsen (1996) showed that contaminants from an unheated source located near the occupant but below the breathing level could result in much higher exposure in a DV room. Later 
CFD simulations by Brohus (2003) indicated that occupant exposure to a contaminant from a thermally-neutral source associated with the entire floor area in a DV room approached the exposure expected for a well-mixed room and confirmed that exposures in a DV room with warm supply air also approached well-mixed room exposures.

The presumption that air entrained into an occupant's thermal plume will be cleaner than the local air in the room could be in conflict with the 'personal cloud' effect, which has been described and measured by others (Clayton, et al. 1993, Ferro et al. 2004, Thatcher and Layton 1995). Based on CFD studies, Zhao et al. (2004) predicted that concentrations of $2.5 \mathrm{um}$ and $10 \mathrm{um}$ particles generated by occupant-related sources will be higher at most locations in a modeled office space with a DV system relative to one with a MV system. Based on a similar CFD study, Zhang and Chen (2004) reported that particle concentrations in the breathing zone of a DV space could vary considerably and be significantly higher than in the lower portion of the room depending on the particle source location. Holmberg and Chen (2003) also predicted higher particle concentrations in the breathing zone of a classroom with DV compared to one with MV. They found that using a low supply and exhaust that forces flow in a horizontal direction could reduce breathing zone particle concentrations in the DV zone. However, such a system was predicted to result in steep temperature gradients and its impact on other air quality parameters and thermal comfort is unknown.

$\mathrm{Li}$ et al. (2004) report CFD studies of the robustness of the air distribution for different air distribution systems. Robustness is defined as the capability of meeting the ventilation requirements under varying operational conditions. They found that floor supply with ceiling return did not always result in conventional DV performance if the heat sources are not concentrated and that a MV system with ceiling supplies with ceiling returns produced the best robustness over a wide range of supply velocities. Nielsen et al. (2003) also looked at the impact of varying supply airflow on thermal comfort parameters in a test chamber. They found that for the DV system the predicted dissatisfied due to draft increases with increasing supply airflow, while predicted dissatisfied due to vertical temperature gradient decreases with increasing supply flow such that an optimal airflow rate for thermal comfort exists. For the case examined, a very narrow range of acceptable flow rate exists if a criterion of fewer than $20 \%$ dissatisfied is to be met.

Mattsson et al. (2003) studied the impact of DV and MV systems on the vertical distribution of contaminants in occupied classrooms of a Swedish elementary school. Measurements of particles, cat allergen, and $\mathrm{CO}_{2}$ showed that, while $\mathrm{CO}_{2}$ was about $10 \%$ lower at breathing height with the DV system, there was no significant difference in particle or cat allergen concentrations. Based on observation, physical activity of the pupils is believed to have had a significant mixing effect in the rooms.

Recent work studying the application of DV systems to warmer climates has also been reported. Livchak and Nall (2000) describe the potential for humidity control problems for typical DV systems in hot and humid climates due to high supply air temperatures and water vapor stratification and propose modifications to avoid these problems. Kosonen (2002) found that humidity ratios were significantly stratified in a Malaysian factory with DV and suggested that this stratification was an unaccounted for benefit which could lead to higher energy savings. However, measured relative humidity in some zones was over 65 \% near the floor, which could be a concern. Xie et al. (2003) and Yu et al. (2003) report chamber studies that evaluated thermal comfort and occupant perception of air quality for both a DV and MV system in Singapore. They found that occupants were comfortable at a slightly higher average room temperature in a DV room than a MV room and reported no significant difference in perceived air quality between the two systems. However, the study was limited due to small sample size and range of conditions studied. 
For various reasons, DV systems may not always yield the predicted improvements in performance in real-world practice. However, the actual performance has not been extensively studied. Melikov et al. (2005) reported a field study on occupant comfort and perceptions of air quality. They surveyed 227 occupants in 10 new or recently renovated office buildings with DV and found that $49 \%$ of occupants were daily bothered by an uncomfortable room temperature and $48 \%$ were not satisfied with the air quality. Among reasons cited for the occupant dissatisfaction were intentional or accidental blocking of diffusers and, in an attempt to reconcile occupant complaints, building managers setting supply air temperatures too high to achieve the intended stratification.

One of the limitations of DV systems is the relatively small heat load intensity that it may be able to remove. One alternative to increasing the DV cooling system capacity is to combine DV systems with a cooled ceiling (CC). While both the REHVA and ASHRAE guides discuss briefly discuss CC systems, Novoselac and Srebric (2002a) extensively reviewed DV/CC combination systems. They conclude that such systems may provide IAQ and energy advantages over conventional systems but such systems have complex interactions of many design parameters, are very sensitive and may use more or less energy than a VAV system depending on many factors (i.e., loads, climate, system configuration). They also state that application for U.S. buildings would be enhanced through a combined analysis approach using a tool that combines simulation of airflow patterns, building thermal behavior, HVAC systems, and climate data, as well as design guidelines that account for both active and passive contaminant sources. In related work, Novoselac and Srebric (2002b) report on CFD studies comparing CC/DV and CC/MV performance in removing contaminants from various sources and report that performance is similar between the two system types for contaminants not associated with heat sources (specifically, volatile organic compounds (VOC) from carpet and walls).

\subsection{Energy and Cost}

In Europe, the primary driving force for use of DV systems has been the potential for improved IAQ. In fact, the REHVA Guide states that generally the energy consumption of DV does not differ very much from MV. Nevertheless, a major factor in the consideration of DV systems for non-industrial applications in the U.S. is the possibility of significant energy savings.

While there is a lack of field data evaluating costs or energy savings for DV systems in U.S. climates, there have been several simulation studies, which are summarized in Table 1. Different measures of energy savings are presented for different studies depending on the detail included in the individual reports. Also, the table includes only those studies that included enough detail to reasonably determine that the savings are attributable to the use of a DV system. Other studies have reported savings without sufficient detail. For example, Holland and Livchak (2002) report 55 \% savings for a school in Minnesota using a "Design Base” system relative to a "Code Base” system. However, since changes between the systems include many energy saving factors in addition to the use of DV (e.g., energy recovery systems, occupancy sensors, variable speed drive pumps, etc.), it is impossible to determine what portion of the savings is due to use of DV.

In the earliest published study comparing the energy use of DV and MV systems in U.S. climates, Seppanen et al. (1989) used the DOE2.1C building simulation program to simulate energy use for south, north and core zones of an office building in four cities (Minneapolis, Seattle, Atlanta, and El Paso). Several types of both MV and DV systems were studied including both VAV and CAV systems that in some cases included economizers and heat recovery. Because the study did not report detailed results, it is not included in Table 1. Typically, they found cooling energy saving offset by a heating energy penalty for the DV system, thus the net effect depended on climate and zone orientation. They did not report separate fan energy use. Overall, they predicted that DV saved energy compared to the MV systems with CAV but used slightly more energy than the MV systems 
with VAV. However, unlike other reports discussed below and included in Table 1, they did not simulate a DV system with economizer, which would be expected to provide further cooling energy savings in many climates at the expense of increased fan energy. Seppanen et al. also estimated first costs for a DV system relative to a MV-VAV system with an economizer and found that the DV system would cost slightly more for core zones and significantly more in perimeter zones due to the need for cooling ceiling panels to meet the larger cooling load. They caution that the first costs were difficult to estimate due to the lack of a complete design and bidding process and a lack of U.S. suppliers for some components at that time.

Bourassa et al. (2002) simulated the potential energy savings of DV systems and other low energy cooling technologies for nonresidential buildings in 4 California climates. More detailed results for this study are available in a separate California Energy Commission report (CEC 2003). The study compared different combinations of technologies but the only results considered here are the comparison of a DV system to a typical MV system. The building simulated was a generic 6-story building with a variable air volume (VAV) system but the simulations varied the occupancy (12 $\mathrm{h}$ and $24 \mathrm{~h}$ ) and minimum outdoor air (15\% with economizer and $100 \%)$. Simulations were performed using the DOE2 simulation program with increased cooling supply air temperature (from $12.8^{\circ} \mathrm{C}$ to $18.3^{\circ} \mathrm{C}$ ) and zone air setpoint (from $23.3^{\circ} \mathrm{C}$ to $28.9^{\circ} \mathrm{C}$ ) relative to the baseline VAV system to account for the inability of the program to correctly model stratified spaces. Due to this limitation, the authors note that the DV results should be treated with caution until a more detailed model is available. As seen in Table 1, the reported annual energy savings ranged from $30 \%$ to $60 \%$ depending on building and climate. Per the authors, the majority of the savings are due to the increased availability of free cooling hours due to the higher supply air temperature for the DV system. Generally, small reductions were seen in peak cooling demand, as peak hours are not coincident with economizer use.

Chen and Glicksman (1999) simulated the potential energy savings for DV systems in a classroom, a small office and a workshop in five U.S. climates (Seattle, Portland, Phoenix, New Orleans, Nashville) using an energy balance program with a temperature model developed to account for the non-uniform temperature distribution. The minimum outdoor air for all spaces was reduced from $10 \mathrm{~L} / \mathrm{s}$ per person for the MV system to $7.7 \mathrm{~L} / \mathrm{s}$ per person for the DV system on the assumption of improved ventilation effectiveness. This is greater than the reduction that would be allowed using the ASHRAE Standard 62.1-2004 default air change effectiveness values, which correspond to a $20 \%$ reduction during cooling and no reduction during heating. The total energy savings reported range from $2 \%$ to $38 \%$. The largest savings were reported for the classroom, which were primarily due to the significant reduction in outdoor airflow. All climate and building combinations showed increased fan use offset by reductions in both heating and cooling energy. However, it is not possible to determine what the savings would have been if the modeled designs had followed the ASHRAE requirements for outdoor air. Also, these savings are smaller than the Bourassa study, but the difference may be partially because the Bourassa study did not include any extreme climates. Larger percent savings are estimated for mild climates due to increased economizer use. Chen and Glicksman also estimated first costs for an office building with one hundred 19- $\mathrm{m}^{2}$ offices for both the DV and MV systems. Neglecting the cost of a potentially needed perimeter heating system, first costs for the DV system were $3 \%$ to 6 \% less than for the MV system. However, inclusion of the perimeter system results in an increase of up to $20 \%$ in first costs for the DV system relative to the MV system.

Zhivov and Rymkevich (1998) compared predicted heating and cooling energy use in five U.S. cities for a 334- $\mathrm{m}^{2}$ restaurant dining area with MV and DV systems. Simulations were performed with the BLAST modeling program (Building Systems Laboratory 1999). Two outdoor air cases were considered for each system type: one with constant outdoor air and another with variable outdoor air 
according to a schedule table. As seen in Table 1, they estimated annual cooling energy savings for the DV system ranging from a low of $13 \%$ in the hot-humid climate of Miami to a high of $45 \%$ in the mild climate of Seattle for the constant outdoor airflow case. However, they predicted heating energy increases ranging from $11 \%$ to $30 \%$. The relative comparison in energy use between the DV and MV systems were generally similar for the variable outdoor airflow case. Although their results are not directly comparable since they did not calculate fan energy separately from heating and cooling, the prediction of significant increases in heating energy use by Zhivov and Rymkevich directly contradicts the predictions of Chen and Glicksman. One significant difference between the studies that may explain this difference is the assumption of much lower outdoor airflow rates by Chen and Glicksman. Zhivov and Rymkevich also calculated annual heating and cooling energy costs using regional gas and electricity costs from 1996 and estimated that the DV system reduced costs by $12 \%$ to $19 \%$ relative to the MV system. These predicted savings would be smaller today because gas prices have risen much faster than electricity prices since 1996.

Roth et al. (2002) estimated the energy savings for a DV system relative to a MV system for a small office building in five U.S. cities. Both systems were specified as VAV systems with $3.7 \mathrm{~m} / \mathrm{h} \cdot \mathrm{m}^{2}$ of outdoor air. As shown in Table 1, they found annual cooling energy savings ranging from $29 \%$ to $75 \%$ with the largest percent savings being in the mild San Francisco climate due to a significant economizer effect. Offsetting the cooling savings was an increase in fan energy use ranging from $25 \%$ to $49 \%$. These estimates did not include detailed whole building simulation but rather employed binned building load data and several simplifying assumptions. They did not include heating energy or total energy estimates. Roth et al. also calculated the potential simple payback period of a DV system relative to a MV system for a small office using data from Chen and Glicksman (1999). The result ranged from a low of 3.4 years in the South region to a high of 24 years in the Pacific region. The relatively lower annual energy use in the Pacific region caused a high payback period despite larger percent savings in energy for the DV system.

\section{Table 1 Summary of Displacement Ventilation Simulation Study Results}

\begin{tabular}{|c|c|c|c|c|c|c|}
\hline Study & Type & Location & $\begin{array}{l}\text { Total annual } \\
\text { fan energy } \\
\text { savings } \\
(\%)\end{array}$ & $\begin{array}{l}\text { Total annual } \\
\text { cooling } \\
\text { energy } \\
\text { savings (\%) }\end{array}$ & $\begin{array}{l}\text { Total annual } \\
\text { heating } \\
\text { energy } \\
\text { savings(\%) }\end{array}$ & $\begin{array}{l}\text { Total } \\
\text { Energy } \\
\text { Savings } \\
(\%)\end{array}$ \\
\hline \multirow[t]{12}{*}{ Bourassa } & $\begin{array}{l}\text { Office } \\
\text { (12 h \& Min OA) }\end{array}$ & Oakland & NA & NA & NA & 57 \\
\hline & & San Diego & NA & NA & NA & 44 \\
\hline & & Pasadena & NA & NA & NA & 34 \\
\hline & & Sacramento & NA & NA & NA & 30 \\
\hline & $\begin{array}{l}\text { Office } 2 \\
\text { (24 h \& Min OA) }\end{array}$ & Oakland & NA & NA & NA & 60 \\
\hline & & San Diego & NA & NA & NA & 48 \\
\hline & & Pasadena & NA & NA & NA & 40 \\
\hline & & Sacramento & NA & NA & NA & 36 \\
\hline & $\begin{array}{l}\text { Building (12 h \& } \\
100 \% \text { OA) }\end{array}$ & Oakland & NA & NA & NA & 59 \\
\hline & & San Diego & NA & NA & NA & 49 \\
\hline & & Pasadena & NA & NA & NA & 49 \\
\hline & & Sacramento & NA & NA & NA & 38 \\
\hline
\end{tabular}




\begin{tabular}{|c|c|c|c|c|c|c|}
\hline Study & Type & Location & $\begin{array}{l}\text { Total annual } \\
\text { fan energy } \\
\text { savings } \\
(\%)\end{array}$ & $\begin{array}{l}\text { Total annual } \\
\text { cooling } \\
\text { energy } \\
\text { savings (\%) } \\
\end{array}$ & $\begin{array}{l}\text { Total annual } \\
\text { heating } \\
\text { energy } \\
\text { savings(\%) } \\
\end{array}$ & $\begin{array}{l}\text { Total } \\
\text { Energy } \\
\text { Savings } \\
(\%) \\
\end{array}$ \\
\hline & $\begin{array}{l}\text { Lab1 (24 h \& } 100 \\
\% \text { OA) }\end{array}$ & Oakland & NA & NA & NA & 60 \\
\hline & & San Diego & NA & NA & NA & 53 \\
\hline & & Pasadena & NA & NA & NA & 53 \\
\hline & & Sacramento & NA & NA & NA & 44 \\
\hline \multirow[t]{15}{*}{ Chen } & Office & Seattle & -18 & 70 & 11 & 8 \\
\hline & Classroom & Seattle & -6 & 70 & 60 & 33 \\
\hline & Workshop & Seattle & -20 & 70 & 50 & 5 \\
\hline & Office & $\begin{array}{l}\text { Portland, } \\
\text { ME }\end{array}$ & -17 & 44 & 18 & 12 \\
\hline & Classroom & $\begin{array}{l}\text { Portland, } \\
\text { ME }\end{array}$ & -12 & 44 & 66 & 38 \\
\hline & Workshop & $\begin{array}{l}\text { Portland, } \\
\text { ME }\end{array}$ & -17 & 38 & 67 & 12 \\
\hline & Office & Phoenix & -18 & 25 & 20 & 7 \\
\hline & Classroom & Phoenix & -25 & 26 & 50 & 6 \\
\hline & Workshop & Phoenix & -32 & 25 & NA & 2 \\
\hline & Office & New Orleans & -19 & 33 & 28 & 15 \\
\hline & Classroom & New Orleans & -18 & 35 & 50 & 17 \\
\hline & Workshop & New Orleans & -28 & 32 & NA & 11 \\
\hline & Office & Nashville & -25 & 33 & 20 & 10 \\
\hline & Classroom & Nashville & -17 & 36 & 63 & 20 \\
\hline & Workshop & Nashville & -26 & 35 & 60 & 11 \\
\hline \multirow[t]{5}{*}{ Roth } & Office & Albuquerque & -49 & 40 & NA & NA \\
\hline & & Chicago & -46 & 38 & NA & NA \\
\hline & & Fort Worth & -48 & 29 & NA & NA \\
\hline & & New York & -44 & 40 & NA & NA \\
\hline & & $\begin{array}{l}\text { San } \\
\text { Francisco }\end{array}$ & -25 & 75 & NA & NA \\
\hline \multirow[t]{5}{*}{ Zhivov } & Restaurant & Albuquerque & NA & 22 & -21 & 8 \\
\hline & & Miami & NA & 13 & -11 & 13 \\
\hline & & Minneapolis & NA & 29 & -11 & -0.2 \\
\hline & & Phoenix & NA & 18 & -30 & 15 \\
\hline & & Seattle & NA & 45 & -29 & -12 \\
\hline
\end{tabular}




\subsection{Summary}

Perhaps due to societal biases, the European and U.S. literature approach DV systems from almost opposite directions. The European literature emphasizes potential improvements in IAQ that may or may not come with energy savings, while the American literature emphasizes potential energy savings that may be at least partially achieved by lowering minimum ventilation rates while maintaining acceptable IAQ. The literature is replete with articles and reports describing both the potential IAQ and energy benefits of DV as well summarized in both the REHVA guide - from the European perspective - and the ASHRAE guide - from the U.S. perspective. However, a close examination of the literature also reveals the need for caution in considering these claims and care in applying DV systems.

While the potential IAQ advantages of DV are well established in the literature, it is also undeniable that there are limits to these benefits. The reviewed chamber and CFD studies have shown a few such limitations. First, stable thermal stratification, upon which any IAQ advantage relies, depends on a design that considers thermal loads, room configurations, surface temperatures, supply diffuser type, and airflow rates and temperatures. Proper design and operation is also critical to providing an environment that is thermally comfortable to occupants. Even with a proper design, unwanted mixing can occur due to occupant activity or thermal transient events. Also, even with stable thermal stratification, many contaminants may be found at higher concentrations in the occupied portion of the room depending on the source location, source type, and contaminant characteristics. Another thermal and IAQ-related concern is the lack of sufficient study of humidity control in DV spaces.

Numerous simulation studies comparing energy use in various spaces with DV systems and MV systems in U.S. climates have found results ranging from a reduction in total energy use of up to $60 \%$ to an increase of up to $12 \%$. Among studies that reported energy use in separate categories, there was general agreement of decreases in cooling energy use and increases in fan energy use with DV. The studies differed on whether a DV system would result in an increase or decrease in heating energy use. In addition to the many specific building and climate factors that always impact building energy use, a key parameter affecting the potential cooling energy savings was inclusion of an economizer because the higher supply air temperature of a DV system enables use of an economizer during more hours than with a conventional system.

Another key parameter affecting both heating and cooling energy use was whether equal or reduced outdoor airflow was specified for the DV system. Although ASHRAE Standard 62.1-2004 allows a potential $20 \%$ reduction in minimum outdoor airflow rate for DV systems, this allowance should be re-examined in consideration of the recent literature, which clearly shows that successfully achieving thermal stratification does not result in lower contaminant concentrations for all contaminants from all sources. Since the 2004 version of Standard 62.1 bases minimum ventilation rates on separate floor area and occupancy requirements, one alternative that may merit consideration is to allow a reduction for the occupancy-derived portion of the ventilation rate but not to allow it for the floor area-derived portion. This approach may be supported by evidence that DV systems can be very effective at removing occupant-related contaminants but may be less effective at removing contaminants not associated with heat sources. Additionally, if DV systems are used to provide heating in zones when required, future energy analyses should consider an increase in ventilation flow as required by Standard 62.1.

Despite the concerns expressed above, it is clear that DV systems have significant potential to improve IAQ and save energy. However, since DV systems rely on different principles and employ different mechanical components, it is valid to question whether such systems can or should be widely adopted until field studies demonstrate their performance and address the remaining 
concerns. This literature review did not find any field studies of DV systems in U.S. applications. Additionally, some European field studies have raised questions about the thermal and IAQ performance of DV systems.

In the meantime, there are still some applications for which DV systems can readily be applied today. One example is the Howe et al. (2003) description of the application of DV systems to cool a telecommunication equipment room, which found temperature and energy performance advantages for a Colorado climate. Such an application may be ideal for DV because thermal performance is the only major issue, IAQ performance is not as critical a design issue, and the cooling loads may be quite predictable. 


\section{Dedicated Outdoor Air Systems}

\subsection{Review of DOAS}

As with the DV study, the first task undertaken to evaluate DOAS was a review of the published literature describing the design, performance, simulation and case studies of DOAS for commercial buildings. Also, as with DV systems, there has been great interest in DOAS recently. However, less of the work on DOAS has been reported at research conferences and more has been reported in trade and engineering journals, possibly because DOAS are less 'exotic' than DV. Another point to note is that the DOAS review may have missed some reports as the term 'dedicated outdoor air systems' is not universally applied when describing such systems.

\subsubsection{General}

An early article advocating separate handling of the outdoor air and return air was written by Coad (1999). He argues that the concept of a mixing approach that combines outdoor air and return air into one stream for conditioning and delivery may have been adequate for the simpler buildings and HVAC systems of decades ago. He notes that these combined systems are fraught with potential pitfalls in today's more complex buildings and systems, such as VAV systems serving multiple zones. These potential problems range from poor thermal comfort to possible microbial contamination. Since the most substantial water vapor load in many commercial buildings is the outdoor air, the proposed solution is to separate the humidity control and ventilation functions from the control of sensible loads in the building. Any of a variety of systems ranging from central VAV units to fan coil units to radiant heating and cooling panels can then be used to address those sensible loads. A ventilation air-conditioning (VAC) unit is proposed to introduce the outdoor air required by the building, dehumidify that air to or below the desired dew point temperature of the space, filter the air, heat the air if required, and deliver the air directly to all indoor zones. The alternative of mixing the treated outdoor air with recirculated air before delivery is also discussed. A separate VAC unit could incorporate additional energy conservation technology such as ventilation heat recovery and desiccant cooling. One potential disadvantage is the lack of economizer capability since the outdoor airflow rate cannot be increased. Without providing cost details, Coad states that such a system can often be installed within the same budgetary constraints as a conventional system.

In a three-part article, Gatley (2000a, 2000b, 2000c) describes the use of dedicated outdoor air units for delivering dehumidified air to buildings to minimize indoor air quality problems and provide comfort. Advantages of such units cited include better control of building pressurization, more consistent delivery of required outdoor air quantities, and better management of water vapor removal. Additionally, Gatley emphasizes the reduced potential for mold problems through the combination of conditioning the outdoor air to a dew point below $12.8^{\circ} \mathrm{C}$ and pressurizing the building to eliminate infiltration of humid outdoor air. He also discusses the economic viability of enthalpy recovery from exhaust air (ranging from $20 \%$ to $90 \%$ of the supplied outdoor air). Various dehumidification technologies that may be considered are discussed in detail including:

- Exhaust-air/outdoor-air enthalpy exchangers (passive desiccant with equal sensible- and latent-recovery effectiveness).

- Cooling and dehumidifying coil with sensible recovery from exhaust air (with or without evaporative precooling of exhaust) or recuperative dehumidification enhancements:

o Coil-loop run-around precooling and reheating coils (water or glycol)

o Heat-pipe run-around precooling and reheating coils 
o Air-to-air flat-plate heat exchangers for precooling and reheat

o Rotary-wheel heat exchangers for precooling and reheat

o Refrigerant liquid subcooling/air-reheating coil (recuperative enhancement only)

- Exhaust-air/supply-air rotary-wheel latent exchangers (passive desiccant with latent-recovery effectiveness greater than sensible-recovery effectiveness).

- Heat-powered. active desiccant dehumidifiers with a recuperative heat-transfer device between the first segment of the process air and the regeneration air upstream of the primary heat source.

- Cooling and dehumidifying coil with refrigerant hot-gas or condenser-water reheat.

- Cooling and dehumidifying coil with “new-energy reheat” using hot water, steam, or electric reheat coils.

More recent articles have also discussed the basics of DOAS with emphasis on the potential advantages (Mumma 2001a and 2001b and Morris 2003). Mumma (2001a) advocates a system design featuring a preheat coil, enthalpy wheel, dehumidification coil, and a sensible wheel for the DOAS and ceiling radiant cooling panels integrated with the automatic sprinkler system for sensible cooling. Mumma (2001b) discusses the design and operation of ceiling panel cooling systems with a focus on how DOAS address the concerns of condensation, capacity, and cost. Mumma leads an extensive research program focused on DOAS and has published numerous articles detailing the design, control, and performance of these systems are available at http://doas.psu.edu/. Morris (2003) describes a design procedure for selecting the outdoor air unit and cautions that providing dehumidification during unoccupied hours may be necessary in some buildings.

Few published reports on DOAS performance in actual buildings were found. Fischer and Bayer (2003) report a field study of the IAQ and humidity control performance in 10 schools in Georgia. The study included five schools with conventional systems and five with DOAS based on the dual wheel energy recovery combination described by Mumma (i.e., an enthalpy wheel, a cooling coil and a sensible wheel). They report that the schools with conventional systems suffered from poor IAQ (as indicated by higher average levels of total volatile organic compounds (TVOCs), formaldehyde and $\mathrm{CO}_{2}$ ) because the systems provided far less than the ASHRAE Standard 62-1999 required level of outdoor air. The reason for this reduction is that original conventional systems could not adequately maintain space humidities at the higher ventilation level. In contrast, the five schools with DOAS were reported to have lower levels of measured contaminants as the systems could provide acceptable humidity conditions while supplying $7.5 \mathrm{~L} / \mathrm{s}$ per person of ventilation. The schools with DOAS were also reported to have improved comfort and perceived IAQ with lower average absenteeism.

Khattar and Brandemuehl (2002) describe a version of DOAS termed a dual-path system in which outdoor air and return air are separately conditioned and then mixed and delivered to building zones. They discuss the potential advantages of such a system including improved humidity control and avoiding simultaneous heating and cooling. They favor the mixed delivery to independent delivery of the outdoor and return air due to lower first costs, avoidance of cold drafts and potential advantages of equipment packaging. However, a mixed delivery system might not retain the benefit of assured delivery of the required amount of outdoor air to all zones. They describe case study applications of a dual-path system to both a large retail center in Oklahoma and an elementary school in Florida. Field monitoring indicated that indoor RH was maintained in the $40 \%$ to $50 \%$ range in both buildings compared to more typical levels that could be $10 \%$ higher. Khattar et al. 
(2003) briefly describe the performance of various dual-path systems in three Florida elementary schools including the one mentioned above.

\subsubsection{Energy and Cost}

The only energy and cost studies found in the literature were simulation studies. Khattar and Brandemuehl (2002) simulated the energy performance of both the proposed dual-path system described above and a conventional single-path system for a large retail store in Dallas, St. Louis, Washington, D.C., and New Orleans. They imposed a 50 \% RH limit in the building space and did not include heat recovery equipment. They found annual energy savings of $14 \%$ to $27 \%$ and $15 \%$ to $23 \%$ smaller equipment capacity for the dual-path system.

Jeong et al. (2003) reported a simulation study comparing the energy and cost performance of a DOAS with parallel ceiling radiant panels (i.e., the system described by Mumma 2001a and 2001b) to a conventional VAV system with economizer for a $300 \mathrm{~m}^{2}$ office space in an educational building in Pennsylvania. They reported a $42 \%$ reduction in annual energy use for the DOAS system with substantial savings in both fan and chiller energy use. It is unclear how general the results are since the office space simulated was not a whole building, limited details were provided for the building space, and only one climate was considered. Additionally, infiltration was assumed to be negligible.

While not containing any detailed energy analysis, Roth et al. (2002) estimates that DOAS have the potential to reduce heating energy by $10 \%$ and cooling energy by $17 \%$ with possible additional savings through enabling sensible-only zone thermal conditioning approaches such as radiant ceiling cooling panels.

\subsection{Simulation Study}

In addition to the literature review of DOAS, a simulation study was conducted as part of this project to independently evaluate the potential energy savings of DOAS in U.S. commercial buildings.

\subsubsection{Method}

A combined airflow-building energy modeling tool (McDowell, et al. 2003) linking TRNSYS (Klein, et al. 2000) and CONTAM (Dols, et al. 2002) was used to study the energy impact of DOAS on a modern office building in multiple U.S. climate types. Simple HVAC systems representative of system types used in typical buildings are included to model the energy requirements of the buildings along with DOAS models to assess their impact on energy use. Building model parameters are chosen such that the buildings would be consistent with typical new construction and meet current ASHRAE Standard 90.1 (ASHRAE 2001) requirements. Simulations of annual energy employ Typical Meteorological Year, TMY2, files (Marion and Urban 1995) for five cities representing different climates of the U. S. (Miami, FL; Phoenix, AZ; St. Louis, MO; Bismarck, ND; and Minneapolis, MN).

\subsubsection{Model Building}

The building modeled in this study is a two story office building with a total floor area of $2250 \mathrm{~m}^{2}$ and a floorplan as shown in Figure 1. The building has a window-to-wall ratio of 0.2 with a floor-tofloor height of $3.66 \mathrm{~m}$, divided between a $2.74 \mathrm{~m}$ wall height for the occupied space and a $0.92 \mathrm{~m}$ plenum height per floor. The building includes a single elevator shaft. 


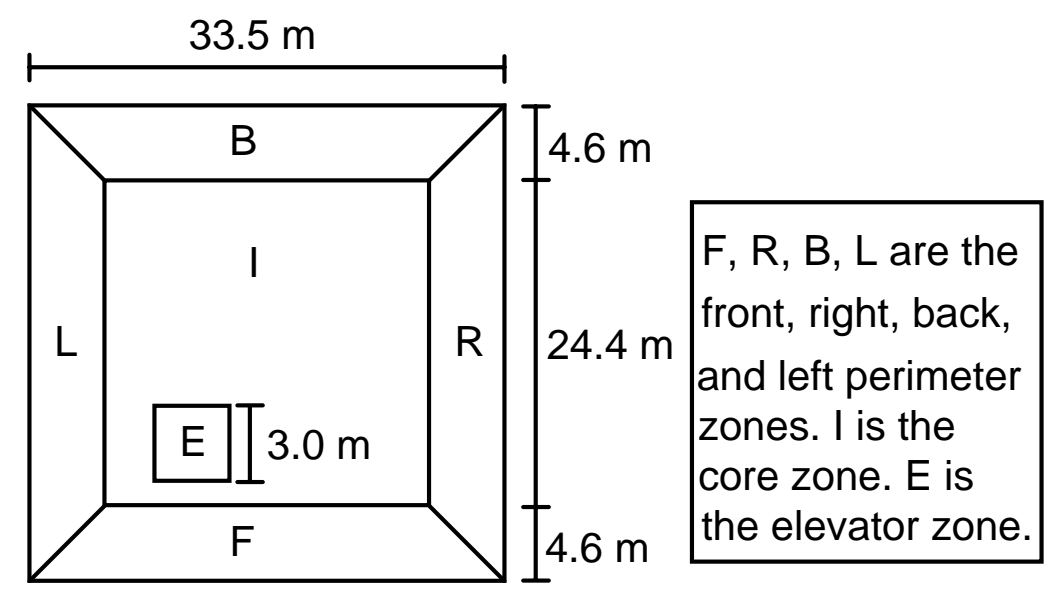

Floor

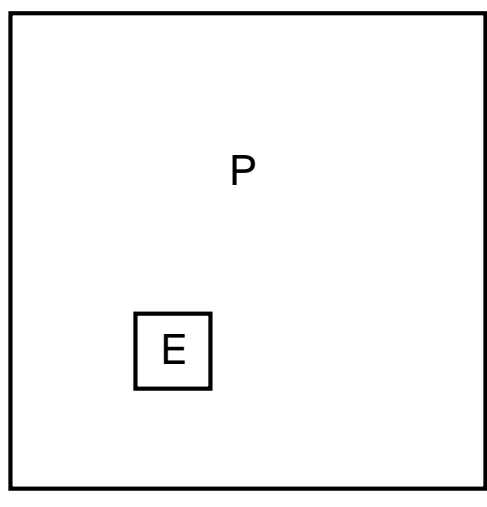

\begin{tabular}{|c|c}
\cline { 1 - 1 } Plenum & $0.9 \mathrm{~m}$ \\
\cline { 1 - 1 } Floor 2 & $2.7 \mathrm{~m}$ \\
\cline { 1 - 1 } Plenum & $0.9 \mathrm{~m}$ \\
\cline { 1 - 1 } Floor 1 & $2.7 \mathrm{~m}$
\end{tabular}

Plenum

Figure 1 Building Floorplan

The building model was developed so that the thermal envelope construction would satisfy the requirements of ASHRAE Standard 90.1-2001. To meet these requirements the wall, roof and slab constructions varied for the different locations as shown in Tables 2 through 5 . The window properties used in the model are a heat loss factor, $\mathrm{U}=3.24 \mathrm{~W} / \mathrm{m}^{2}-\mathrm{K}$ and a solar heat gain coefficient, SHGC $=0.39$ for St. Louis, Bismarck, and Minneapolis and $\mathrm{U}=6.93 \mathrm{~W} / \mathrm{m}^{2}-\mathrm{K}$ and SHGC $=0.25$ for Miami and Phoenix. 
Table 2

External Wall Layer Properties for St. Louis, Miami and Phoenix

\begin{tabular}{|l|r|r|r|r|r|}
\hline & Thickness & Conductivity & \multicolumn{1}{c|}{ Density } & \multicolumn{1}{c|}{$\begin{array}{c}\text { Specific } \\
\text { Heat }\end{array}$} & \multicolumn{1}{c|}{ Resistance } \\
\hline Description & \multicolumn{1}{c|}{$\mathrm{m}$} & \multicolumn{1}{c|}{$\mathrm{W} / \mathrm{m}-\mathrm{K}$} & \multicolumn{1}{c|}{$\mathrm{kg} / \mathrm{m}^{3}$} & \multicolumn{1}{c|}{$\mathrm{kJ} / \mathrm{kg}-\mathrm{K}$} & $\mathrm{m}^{2}-\mathrm{K} / \mathrm{W}$ \\
\hline Face brick & 0.092 & 0.879 & 1922 & 0.921 & 0.10 \\
\hline Vertical wall air layer & & & & & 0.16 \\
\hline Gypsum board & 0.0127 & 0.160 & 800 & 0.837 & 0.079 \\
\hline Steel studs w/mineral wool & 0.089 & 0.0751 & 288 & 1.298 & 1.2 \\
\hline Gypsum board & 0.0159 & 0.160 & 800 & 0.837 & 0.099 \\
\hline
\end{tabular}

Table 3

External Wall Layer Properties for Bismarck and Minneapolis

\begin{tabular}{|l|r|r|r|r|r|}
\cline { 2 - 6 } \multicolumn{1}{l|}{} & Thickness & Conductivity & Density & \multicolumn{1}{c|}{$\begin{array}{c}\text { Specific } \\
\text { Heat }\end{array}$} & Resistance \\
\hline Description & $\mathrm{m}$ & $\mathrm{W} / \mathrm{m}-\mathrm{K}$ & $\mathrm{kg} / \mathrm{m}^{3}$ & $\mathrm{~kJ} / \mathrm{kg}-\mathrm{K}$ & $\mathrm{m}^{2}-\mathrm{K} / \mathrm{W}$ \\
\hline Face brick & 0.092 & 0.879 & 1922 & 0.921 & 0.10 \\
\hline Vertical wall air layer & & & & & 0.16 \\
\hline Gypsum board & 0.0127 & 0.160 & 800 & 0.837 & 0.079 \\
\hline Steel studs w/mineral wool & 0.089 & 0.0751 & 288 & 1.298 & 1.2 \\
\hline Expanded polystyrene & 0.0254 & 0.0277 & 29 & 1.214 & 0.88 \\
\hline Gypsum board & 0.0159 & 0.160 & 800 & 0.837 & 0.099 \\
\hline
\end{tabular}

Table 4

Roof Layer Properties for All Locations

\begin{tabular}{|l|r|r|r|r|r|}
\cline { 2 - 6 } \multicolumn{1}{c|}{} & Thickness & Conductivity & Density & \multicolumn{1}{c|}{$\begin{array}{c}\text { Specific } \\
\text { Heat }\end{array}$} & Resistance \\
\hline Description & $\mathrm{m}$ & $\mathrm{W} / \mathrm{m}-\mathrm{K}$ & $\mathrm{kg} / \mathrm{m}^{3}$ & $\mathrm{~kJ} / \mathrm{kg}-\mathrm{K}$ & $\mathrm{m}^{2}-\mathrm{K} / \mathrm{W}$ \\
\hline Built-up roofing & 0.0095 & 1.63 & 1120 & 1.47 & 0.058 \\
\hline Polyisocyanurate insulation & 0.0634 & 0.0242 & 24 & 1.59 & 2.62 \\
\hline Fiber board sheathing & 0.0128 & 0.0554 & 288 & 1.298 & 0.23 \\
\hline
\end{tabular}


Table 5

Slab Layer Properties for All Locations

\begin{tabular}{|l|r|r|r|r|r|}
\cline { 2 - 6 } \multicolumn{1}{c|}{} & Thickness & Conductivity & Density & Specific Heat & Resistance \\
\hline Description & $\mathrm{m}$ & $\mathrm{W} / \mathrm{m}-\mathrm{K}$ & $\mathrm{kg} / \mathrm{m}^{3}$ & $\mathrm{~kJ} / \mathrm{kg}-\mathrm{K}$ & $\mathrm{m}^{2}-\mathrm{K} / \mathrm{W}$ \\
\hline Concrete normal weight & 0.127 & 1.31 & 2240 & 0.837 & 0.097 \\
\hline
\end{tabular}

The internal gains for the occupied spaces are divided into three parts: lighting, receptacle loads, and occupancy. These gains are all applied using a peak value and fraction of peak schedule. The lighting peak is $10.8 \mathrm{~W} / \mathrm{m}^{2}$, the peak receptacle load is $6.8 \mathrm{~W} / \mathrm{m}^{2}$, and the peak occupant density is 5 persons $/ 100 \mathrm{~m}^{2}$. The fraction of peak schedules are shown in Figures 2 through 4.

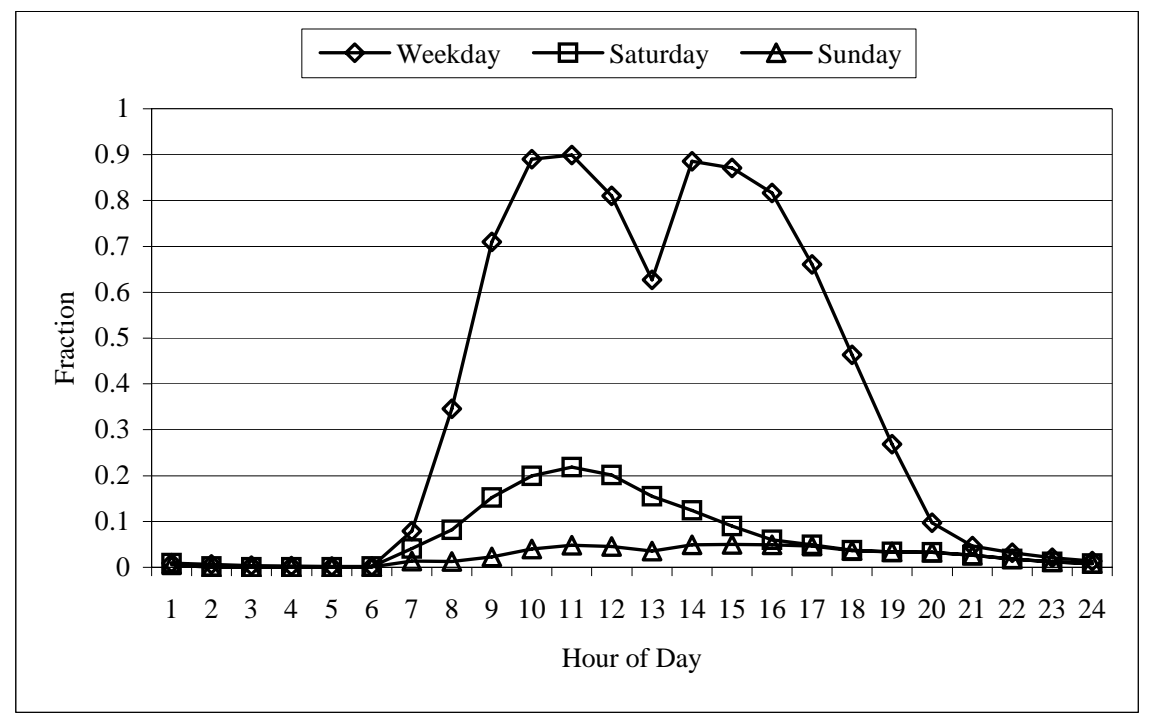

Figure 2 Fractional Occupancy Schedule 


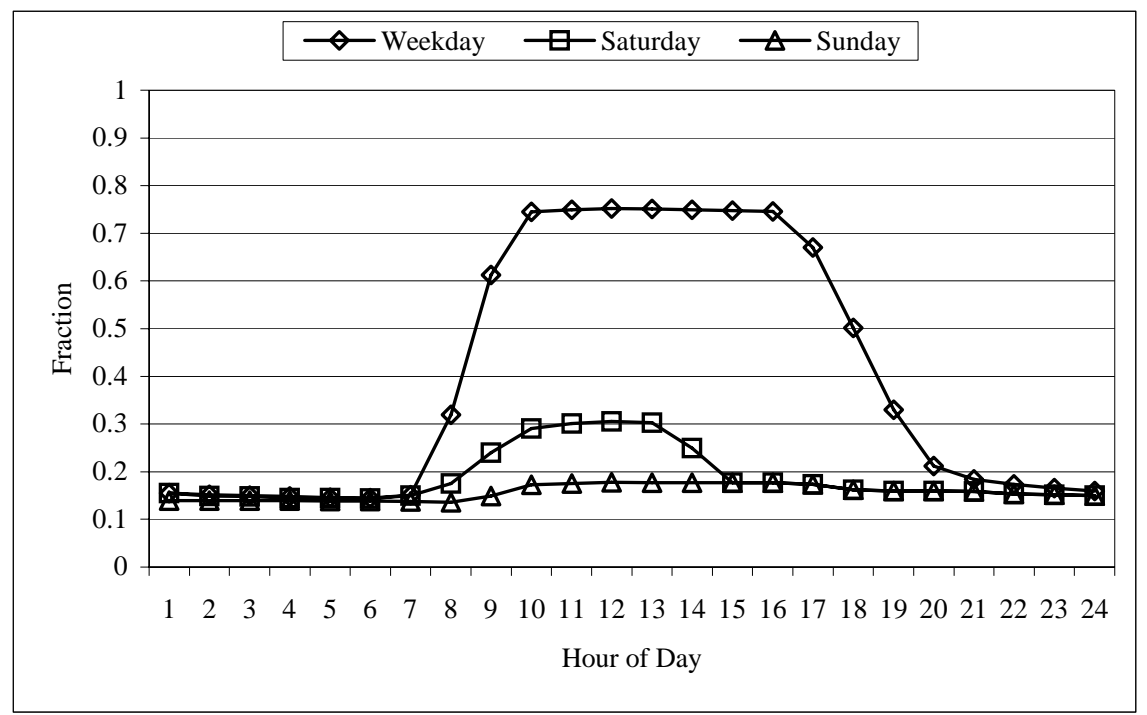

Figure 3 Fractional Lighting Schedule

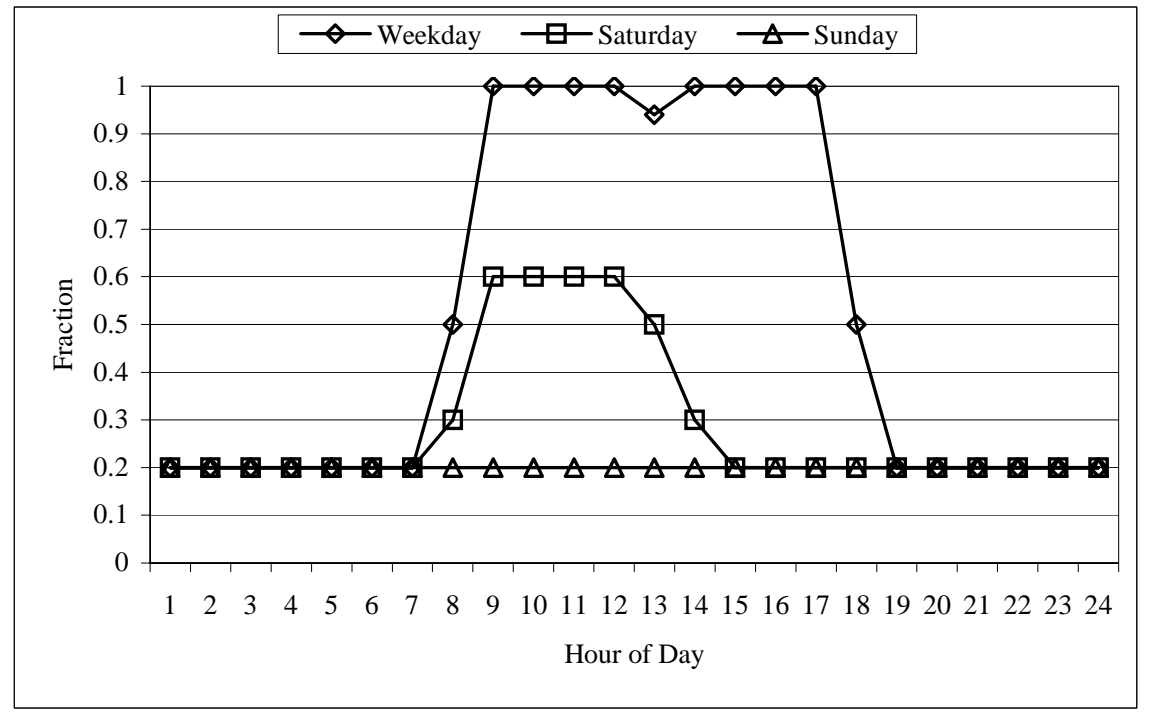

Figure 4 Fractional Receptacle Load Schedule

The thermostats operate on a setpoint with setback/setup basis. The heating setpoint is $21.1^{\circ} \mathrm{C}$ with a setback temperature of $12.8^{\circ} \mathrm{C}$ and the cooling setpoint is $23.9^{\circ} \mathrm{C}$ with a setup temperature of $32.2^{\circ} \mathrm{C}$. The schedule for the thermostat settings differs between weekdays (hours from 6 to 20 at setpoint), Saturdays (hours from 7 to 14 at setpoint) and Sundays (always at setup/setback). For the first hour of operation at setpoint, the system does not bring any outdoor air into the zone.

The amount of outdoor air provided to each zone was $0.43 \mathrm{~L} / \mathrm{s} \cdot \mathrm{m}^{2}$ to meet the requirements of Table 6-1 of ASHRAE Standard 62.1 (ASHRAE 2004). The infiltration and interzonal airflows are calculated using the CONTAM airflow modeling program linked with TRNSYS. The leakage area value used for the exterior envelope of the building is $1.3 \mathrm{~cm}^{2} / \mathrm{m}^{2}$ at $10 \mathrm{~Pa}$, which is equivalent to a leakage rate of $2.6 \mathrm{~m}^{3} /\left(\mathrm{h} \cdot \mathrm{m}^{2}\right)$ at $75 \mathrm{~Pa}$ or approximately equal to the tightest buildings included in a review of commercial building airtightness measurements (Persily 1998). 


\subsubsection{System Models}

Four different HVAC systems were modeled in this study: Baseline, Baseline with Economizer, Simple DOAS, and Full DOAS.

\section{Baseline:}

The baseline system modeled included water source heat pumps (WSHPs) with a cooling tower and a boiler serving the common loop. Each zone has its own WSHP rejecting/extracting heat from the common loop. The outdoor air for each zone is supplied to each individual heat pump and thus the heat pump blower is on at all times when the zone is occupied.

The WSHP is modeled as a single-stage liquid source heat pump. The heat pump conditions a moist air stream by rejecting energy to (cooling mode) or absorbing energy from (heating mode) a liquid stream. This model is based on user-supplied data files containing catalog data for the capacity (both total and sensible in cooling mode), and power, based on the entering water temperature to the heat pump, the entering water flow rate and the airflow rate. Other curve fits are used to modify the capacities and power based on off-design indoor air temperatures.

The boiler is modeled as a simple fluid heater. It is assumed to have enough capacity to always maintain the required temperature and calculates the required input energy to maintain the temperature. In this system the boiler setpoint is the minimum temperature of the liquid stream and the setpoint used in the model is $15.6^{\circ} \mathrm{C}$ and the boiler efficiency is 0.81 (typical for a natural gas boiler). It is also assumed that there are no losses from the tank to ambient.

The cooling tower is modeled as a single cell counterflow cooling tower and sump that rejects heat from the liquid stream to the environment. The tower fan has three speeds: natural convection (no airflow), low and high. The tower performance is calculated using a mass transfer analog.

To compare the different systems, supply and exhaust fans for the ventilation air were added to the base model. Since they only had dampers and ductwork pressure drops to overcome, they were assumed to be $0.37 \mathrm{~kW}$ fans.

\section{Baseline with Economizer:}

The second system added an economizer to the baseline system. Each WSHP has its own economizer that internally determines an appropriate mixture of outdoor and return air that will result in air delivered to the zone at the same enthalpy as air that would be delivered by a cooling coil to satisfy the space load. In the Phoenix model, the economizer is controlled based on temperature rather than enthalpy. The economizers are active any time that the zone is calling for cooling and the outdoor air enthalpy (or temperature in Phoenix) is less than the zone enthalpy (or temperature). If the increased outdoor air is not sufficient to meet the cooling load, then the cooling coil is activated to meet the remaining load.

To make the comparison between the different systems equivalent, the same supply and exhaust fans for the ventilation air were used as in the base model.

\section{Simple DOAS:}

In this system the baseline WSHP system was augmented with a DOAS that consisted of only a preheat coil and an enthalpy wheel. The outdoor air for all of the zones is treated with the exhaust air from all of the zones in a single DOAS system. All of the required ventilation air is brought in using the DOAS, and the WSHP simply treats recirculated air. There is also no economizer system included. 
The preheat coil is modeled as a simple air heating device that maintains the outdoor air above a minimum intake temperature to prevent frost build-up in the enthalpy wheel. The setpoint for this system is $-4^{\circ} \mathrm{C}$. The coil is a gas coil with an efficiency of 0.8 and no external losses to the ambient.

The enthalpy wheel uses a "constant effectiveness - minimum capacitance" approach to model an air to air heat recovery device in which two air streams are passed near each other so that both energy and possibly moisture may be transferred between the streams. In this model both the sensible and latent effectiveness are set to 0.8 . The enthalpy wheel is assumed to be energized and rotating whenever outdoor air is required using a $0.37 \mathrm{~kW}$ motor.

To make the comparison between the different systems equivalent, supply and exhaust fans for the ventilation air were added to the model. They were assumed to be $0.56 \mathrm{~kW}$ fans. The added fan power over the baseline system is to account for pressure losses associated with the ERV components, primarily the enthalpy wheel heat exchanger.

\section{Full DOAS:}

In this system a DOAS was added to the baseline WSHP with the design intent of meeting all of the latent loads of the zones as well as some of the sensible loads. This system consists of a preheat coil, an enthalpy wheel, a cooling coil, a sensible energy wheel and fans (Shank and Mumma 2001). A system diagram is shown in Figure 5. All of the outdoor air for the zones is treated with one DOAS.

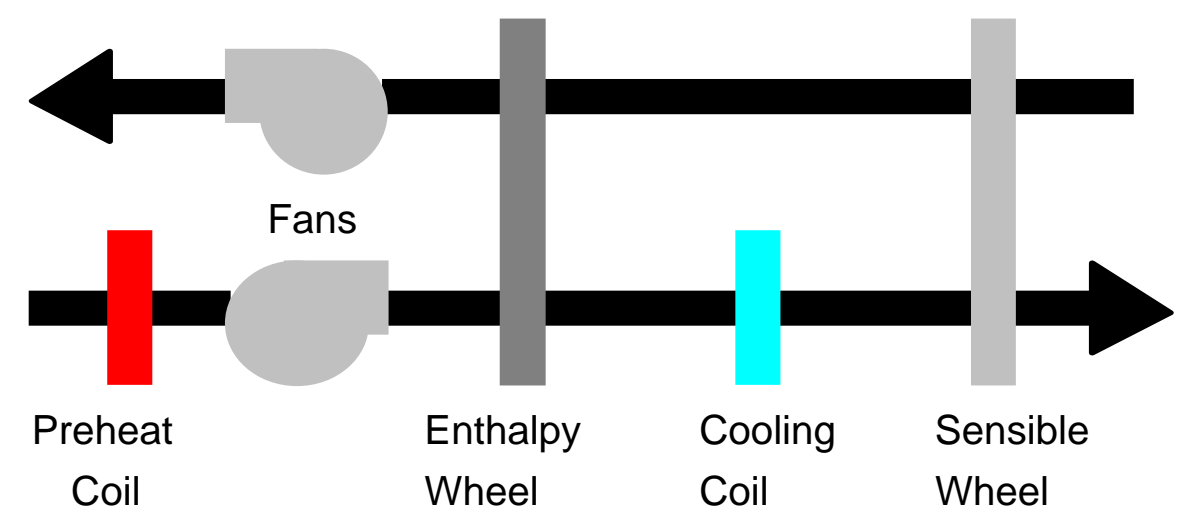

Figure 5 Full DOAS System Diagram

The preheat coil is modeled as a simple air heating device that maintains the outdoor air above a minimum intake temperature to prevent frost build-up in the enthalpy wheel. The setpoint for this system is $-4{ }^{\circ} \mathrm{C}$. The coil is a gas coil with an efficiency of 0.8 and no external loses to the ambient.

In order to meet all of the latent loads of the zones, the enthalpy wheel is controlled based on the outdoor air conditions. It is operated at either full speed, modulated speed to maintain a setpoint or turned off. When the outdoor air enthalpy is higher than the exhaust air enthalpy, the wheel is at full speed. When the outdoor air enthalpy is less than or equal to the exhaust air enthalpy and the outdoor air dewpoint is higher than $11.1^{\circ} \mathrm{C}$, the enthalpy wheel is off. Otherwise the wheel speed is modulated. The full-on and off conditions are straightforward to simulate, but the modulating speed condition offers some difficulties. While modulating the speed of the enthalpy wheel is a widely used method of control, the manufacturer's data rarely contains the information on how the performance varies with changing rotational speed. A modeling method for determining the sensible and latent effectiveness for a modulated enthalpy wheel (Jeong et al. 2003) was modeled in TRNSYS but some shortcomings were determined. The algorithm uses a supply air humidity ratio setpoint, but the referenced paper does not describe the conditions for determining this value. These simulations use the humidity ratio at the supply air drybulb and dewpoint temperatures, though it is 
unusual to control to both these conditions at the same time. The algorithm also uses a value called the driving force ratio (DFR) that determines whether the latent or sensible efficiency leads at the current state of outdoor and return air conditions. It was found in these simulations that problems could arise when the drybulb temperatures or the humidity ratios were very close or when they differed in opposite directions, leading to infinite or negative values for DFR. The calculations were subsequently bounded to prevent this condition from occurring in the model.

Another missing piece of the algorithm was the power required to rotate the enthalpy wheel. A review of catalog data for enthalpy wheels showed that the typical motor size for these types of wheels is $0.37 \mathrm{~kW}$ to $0.56 \mathrm{~kW}$. Since modulating the rotational speed of the enthalpy wheel would likely have only a small effect on the power consumption, it was decided to have the enthalpy wheel draw its $0.37 \mathrm{~kW}$ every timestep that the wheel is energized. The rating values of sensible and latent effectiveness of the enthalpy wheel for this analysis are both 0.8 .

The cooling coil is controlled in two different ways. When the outdoor air dewpoint is greater than $7.2^{\circ} \mathrm{C}$, then the leaving air drybulb temperature is set to $7.2^{\circ} \mathrm{C}$. When the outdoor air dewpoint is less than or equal to $7.2^{\circ} \mathrm{C}$, then the leaving air drybulb temperature is controlled to $12.8^{\circ} \mathrm{C}$. While controlling the leaving air temperature is easy enough, the difficulty lies in determining how much input energy is required. Since there is not a chiller available to provide cold water, the cooling coil would most likely be a direct expansion (DX) coil. Determining the power consumption of a DX coil system (compressor and condenser) is not easy. The approach taken in this model was to regress some available performance data to approximate how the DX coil system COP varies with condenser drybulb and evaporator wetbulb temperatures. The regression equation was then normalized to the COP at standard ARI rating conditions. The resulting equation is:

COP $=$ COPstd $*(1.283142-0.01762 *$ CondDB + 0.017961*EvapWB).

Once the energy required by the cooling coil is determined, the power input to the DX coil system can be approximated.

The sensible wheel is used to provide the required reheat to maintain the supply air temperature above $12.8{ }^{\circ} \mathrm{C}$ with an effectiveness of 0.8 . To approximate the energy required to rotate this wheel the same assumptions were used as for the enthalpy wheel, i.e., $0.37 \mathrm{~kW}$ of power consumed for every timestep the wheel is energized.

Fan power is dependent on the fan curve of the actual fan and the pressure drop through all of the system components. We do not have enough of this information to model the fan performance in detail, so an alternative method to approximate the fan power was used. Based on product selection data for a DOAS unit based on the airflow required and pressure drop through the components it was determined that a $1.12 \mathrm{~kW}$ supply fan and a $0.75 \mathrm{~kW}$ exhaust fan would be required. At every timestep that the DOAS system was active, the fans drew $1.12 \mathrm{~kW}$ and $0.75 \mathrm{~kW}$ of power respectively. The added supply fan power (over the baseline system) is intended to account for pressure losses associated with the preheat coil, cooling coil, enthalpy wheel and sensible wheel, while the added exhaust fan power is associated with losses due to the enthalpy and sensible wheels.

\subsubsection{Results}

The predicted annual electric and gas consumption for the whole office building for each of the systems for the different climates are shown in Table 6 for St Louis, Table 7 for Bismarck, Table 8 for Minneapolis, Table 9 for Miami and Table 10 for Phoenix. 
Table 6 Power Consumption (kJ) for St Louis

\begin{tabular}{|l|c|r|c|c|}
\hline & Base & $\begin{array}{c}\text { Base with } \\
\text { Economizer }\end{array}$ & $\begin{array}{c}\text { Simple } \\
\text { DOAS }\end{array}$ & $\begin{array}{c}\text { Full } \\
\text { DOAS }\end{array}$ \\
\hline Heat Pumps & $1.70 \mathrm{E}+08$ & $1.67 \mathrm{E}+08$ & $1.07 \mathrm{E}+08$ & $6.68 \mathrm{E}+07$ \\
\hline Tower & $7.32 \mathrm{E}+06$ & $7.09 \mathrm{E}+06$ & $7.38 \mathrm{E}+06$ & $4.27 \mathrm{E}+06$ \\
\hline Supply Fan & $4.98 \mathrm{E}+06$ & $4.98 \mathrm{E}+06$ & $7.46 \mathrm{E}+06$ & $1.49 \mathrm{E}+07$ \\
\hline Return Fan & $4.98 \mathrm{E}+06$ & $4.98 \mathrm{E}+06$ & $7.46 \mathrm{E}+06$ & $9.95 \mathrm{E}+06$ \\
\hline Enthalpy Wheel & & & $1.18 \mathrm{E}+07$ & $3.36 \mathrm{E}+06$ \\
\hline Cooling Coil & & & & $3.09 \mathrm{E}+07$ \\
\hline Sensible Wheel & & & & $2.60 \mathrm{E}+06$ \\
\hline Total Electric & $\mathbf{1 . 8 7 E + 0 8}$ & $\mathbf{1 . 8 4 E + 0 8}$ & $\mathbf{1 . 4 1 E + 0 8}$ & $\mathbf{1 . 3 3 E + 0 8}$ \\
\hline & & & & \\
\hline Boiler & $1.14 \mathrm{E}+08$ & $1.14 \mathrm{E}+08$ & $5.01 \mathrm{E}+07$ & $5.42 \mathrm{E}+07$ \\
\hline Preheat & & & $6.06 \mathrm{E}+06$ & $6.06 \mathrm{E}+06$ \\
\hline Total Gas & $\mathbf{1 . 1 4 E + 0 8}$ & $\mathbf{1 . 1 4 E + 0 8}$ & $\mathbf{5 . 6 1 E + 0 7}$ & $\mathbf{6 . 0 2 E + 0 7}$ \\
\hline
\end{tabular}

Table 7 Power Consumption (kJ) for Bismarck

\begin{tabular}{|l|r|r|r|c|}
\hline & Base & $\begin{array}{c}\text { Base with } \\
\text { Economizer }\end{array}$ & $\begin{array}{l}\text { Simple } \\
\text { DOAS }\end{array}$ & $\begin{array}{c}\text { Full } \\
\text { DOAS }\end{array}$ \\
\hline Heat Pumps & $1.64 \mathrm{E}+08$ & $1.63 \mathrm{E}+08$ & $7.82 \mathrm{E}+07$ & $5.85 \mathrm{E}+07$ \\
\hline Tower & $2.88 \mathrm{E}+06$ & $2.73 \mathrm{E}+06$ & $2.77 \mathrm{E}+06$ & $8.97 \mathrm{E}+05$ \\
\hline Supply Fan & $4.98 \mathrm{E}+06$ & $4.98 \mathrm{E}+06$ & $7.46 \mathrm{E}+06$ & $1.49 \mathrm{E}+07$ \\
\hline Return Fan & $4.98 \mathrm{E}+06$ & $4.98 \mathrm{E}+06$ & $7.46 \mathrm{E}+06$ & $9.95 \mathrm{E}+06$ \\
\hline Enthalpy Wheel & & & $1.18 \mathrm{E}+07$ & $2.86 \mathrm{E}+06$ \\
\hline Cooling Coil & & & & $1.54 \mathrm{E}+07$ \\
\hline Sensible Wheel & & & & $1.41 \mathrm{E}+06$ \\
\hline Total Electric & $\mathbf{1 . 7 7 E + 0 8}$ & $\mathbf{1 . 7 5 E + 0 8}$ & $\mathbf{1 . 0 8 E + 0 8}$ & $\mathbf{1 . 0 4 E + 0 8}$ \\
\hline & & & & \\
\hline Boiler & $2.71 \mathrm{E}+08$ & $2.71 \mathrm{E}+08$ & $1.54 \mathrm{E}+08$ & $1.59 \mathrm{E}+08$ \\
\hline Preheat & & & $3.57 \mathrm{E}+07$ & $3.57 \mathrm{E}+07$ \\
\hline Total Gas & $\mathbf{2 . 7 1 E + 0 8}$ & $\mathbf{2 . 7 1 E + 0 8}$ & $\mathbf{1 . 9 0 E + 0 8}$ & $\mathbf{1 . 9 5 E + 0 8}$ \\
\hline
\end{tabular}


Table 8 Power Consumption (kJ) for Minneapolis

\begin{tabular}{|l|r|r|r|c|}
\hline & Base & $\begin{array}{c}\text { Base with } \\
\text { Economizer }\end{array}$ & $\begin{array}{c}\text { Simple } \\
\text { DOAS }\end{array}$ & $\begin{array}{c}\text { Full } \\
\text { DOAS }\end{array}$ \\
\hline Heat Pumps & $1.57 \mathrm{E}+08$ & $1.55 \mathrm{E}+08$ & $8.87 \mathrm{E}+07$ & $5.92 \mathrm{E}+07$ \\
\hline Tower & $4.00 \mathrm{E}+06$ & $3.84 \mathrm{E}+06$ & $3.85 \mathrm{E}+06$ & $1.46 \mathrm{E}+06$ \\
\hline Supply Fan & $4.98 \mathrm{E}+06$ & $4.98 \mathrm{E}+06$ & $7.46 \mathrm{E}+06$ & $1.49 \mathrm{E}+07$ \\
\hline Return Fan & $4.98 \mathrm{E}+06$ & $4.98 \mathrm{E}+06$ & $7.46 \mathrm{E}+06$ & $9.95 \mathrm{E}+06$ \\
\hline Enthalpy Wheel & & & $1.18 \mathrm{E}+07$ & $3.04 \mathrm{E}+06$ \\
\hline Cooling Coil & & & & $2.12 \mathrm{E}+07$ \\
\hline Sensible Wheel & & & & $1.88 \mathrm{E}+06$ \\
\hline Total Electric & $\mathbf{1 . 7 1 E + 0 8}$ & $\mathbf{1 . 6 9 E}+\mathbf{0 8}$ & $\mathbf{1 . 1 9 E}+\mathbf{0 8}$ & $\mathbf{1 . 1 2 E + 0 8}$ \\
\hline & & & & \\
\hline Boiler & $2.54 \mathrm{E}+08$ & $2.55 \mathrm{E}+08$ & $1.53 \mathrm{E}+08$ & $1.39 \mathrm{E}+08$ \\
\hline Preheat & & & $2.76 \mathrm{E}+07$ & $2.76 \mathrm{E}+07$ \\
\hline Total Gas & $\mathbf{2 . 5 4 E + 0 8}$ & $\mathbf{2 . 5 5 E + 0 8}$ & $\mathbf{1 . 8 1 E + 0 8}$ & $\mathbf{1 . 6 6 E + 0 8}$ \\
\hline
\end{tabular}

Table 9 Power Consumption (kJ) for Miami

\begin{tabular}{|l|c|c|c|c|}
\hline & Base & $\begin{array}{c}\text { Base with } \\
\text { Economizer }\end{array}$ & $\begin{array}{c}\text { Simple } \\
\text { DOAS }\end{array}$ & $\begin{array}{c}\text { Full } \\
\text { DOAS }\end{array}$ \\
\hline Heat Pumps & $3.02 \mathrm{E}+08$ & $3.00 \mathrm{E}+08$ & $2.39 \mathrm{E}+08$ & $1.47 \mathrm{E}+08$ \\
\hline Tower & $1.90 \mathrm{E}+07$ & $1.88 \mathrm{E}+07$ & $1.81 \mathrm{E}+07$ & $1.33 \mathrm{E}+07$ \\
\hline Supply Fan & $4.98 \mathrm{E}+06$ & $4.98 \mathrm{E}+06$ & $7.46 \mathrm{E}+06$ & $1.49 \mathrm{E}+07$ \\
\hline Return Fan & $4.98 \mathrm{E}+06$ & $4.98 \mathrm{E}+06$ & $7.46 \mathrm{E}+06$ & $9.95 \mathrm{E}+06$ \\
\hline Enthalpy Wheel & & & $1.18 \mathrm{E}+07$ & $4.75 \mathrm{E}+06$ \\
\hline Cooling Coil & & & & $6.42 \mathrm{E}+07$ \\
\hline Sensible Wheel & & & & $4.80 \mathrm{E}+06$ \\
\hline Total Electric & $\mathbf{3 . 3 1 E + 0 8}$ & $\mathbf{3 . 2 9 E}+\mathbf{0 8}$ & $\mathbf{2 . 8 4 E + 0 8}$ & $\mathbf{2 . 5 9 E + 0 8}$ \\
\hline & & & & \\
\hline Boiler & $3.26 \mathrm{E}+05$ & $3.26 \mathrm{E}+05$ & $3.26 \mathrm{E}+05$ & $3.26 \mathrm{E}+05$ \\
\hline Preheat & & & $0.00 \mathrm{E}+00$ & $0.00 \mathrm{E}+00$ \\
\hline Total Gas & $\mathbf{3 . 2 6 E + 0 5}$ & $\mathbf{3 . 2 6 E + 0 5}$ & $\mathbf{3 . 2 6 E + 0 5}$ & $\mathbf{3 . 2 6 E + 0 5}$ \\
\hline
\end{tabular}


Table 10 Power Consumption (kJ) for Phoenix

\begin{tabular}{|l|r|r|r|c|}
\hline & \multicolumn{1}{|c|}{ Base } & $\begin{array}{c}\text { Base with } \\
\text { Economizer }\end{array}$ & $\begin{array}{c}\text { Simple } \\
\text { DOAS }\end{array}$ & $\begin{array}{c}\text { Full } \\
\text { DOAS }\end{array}$ \\
\hline Heat Pumps & $2.49 \mathrm{E}+08$ & $2.46 \mathrm{E}+08$ & $1.87 \mathrm{E}+08$ & $1.51 \mathrm{E}+08$ \\
\hline Tower & $1.16 \mathrm{E}+07$ & $1.14 \mathrm{E}+07$ & $1.13 \mathrm{E}+07$ & $1.01 \mathrm{E}+07$ \\
\hline Supply Fan & $4.98 \mathrm{E}+06$ & $4.98 \mathrm{E}+06$ & $7.46 \mathrm{E}+06$ & $1.49 \mathrm{E}+07$ \\
\hline Return Fan & $4.98 \mathrm{E}+06$ & $4.98 \mathrm{E}+06$ & $7.46 \mathrm{E}+06$ & $9.95 \mathrm{E}+06$ \\
\hline Enthalpy Wheel & & & $1.18 \mathrm{E}+07$ & $3.37 \mathrm{E}+06$ \\
\hline Cooling Coil & & & & $2.34 \mathrm{E}+07$ \\
\hline Sensible Wheel & & & & $1.67 \mathrm{E}+06$ \\
\hline Total Electric & $\mathbf{2 . 7 1 E + 0 8}$ & $\mathbf{2 . 6 7 E + 0 8}$ & $\mathbf{2 . 2 6 E}+\mathbf{0 8}$ & $\mathbf{2 . 1 4 E + 0 8}$ \\
\hline & & & & \\
\hline Boiler & $3.70 \mathrm{E}+06$ & $3.84 \mathrm{E}+06$ & $1.41 \mathrm{E}+06$ & $1.86 \mathrm{E}+06$ \\
\hline Preheat & & & $0.00 \mathrm{E}+00$ & $0.00 \mathrm{E}+00$ \\
\hline Total Gas & $\mathbf{3 . 7 0 E + 0 6}$ & $\mathbf{3 . 8 4 E + 0 6}$ & $\mathbf{1 . 4 1 E + 0 6}$ & $\mathbf{1 . 8 6 E + 0 6}$ \\
\hline
\end{tabular}

From the annual energy consumption, annual HVAC energy costs were calculated assuming \$0.08 per kWh for electricity and \$0.60 per therm for natural gas. As shown in Figure 6, the simple DOAS resulted in savings ranging from $14 \%$ to $37 \%$ and the full DOAS in slightly higher savings ranging from $21 \%$ to $38 \%$. Although modeling different systems, building spaces and loads, other simulation studies have reported predicted savings in a similar range of $14 \%$ to $27 \%$ (Khattar and Brandemuehl 2002) and 42 \% (Jeong et al. 2003).

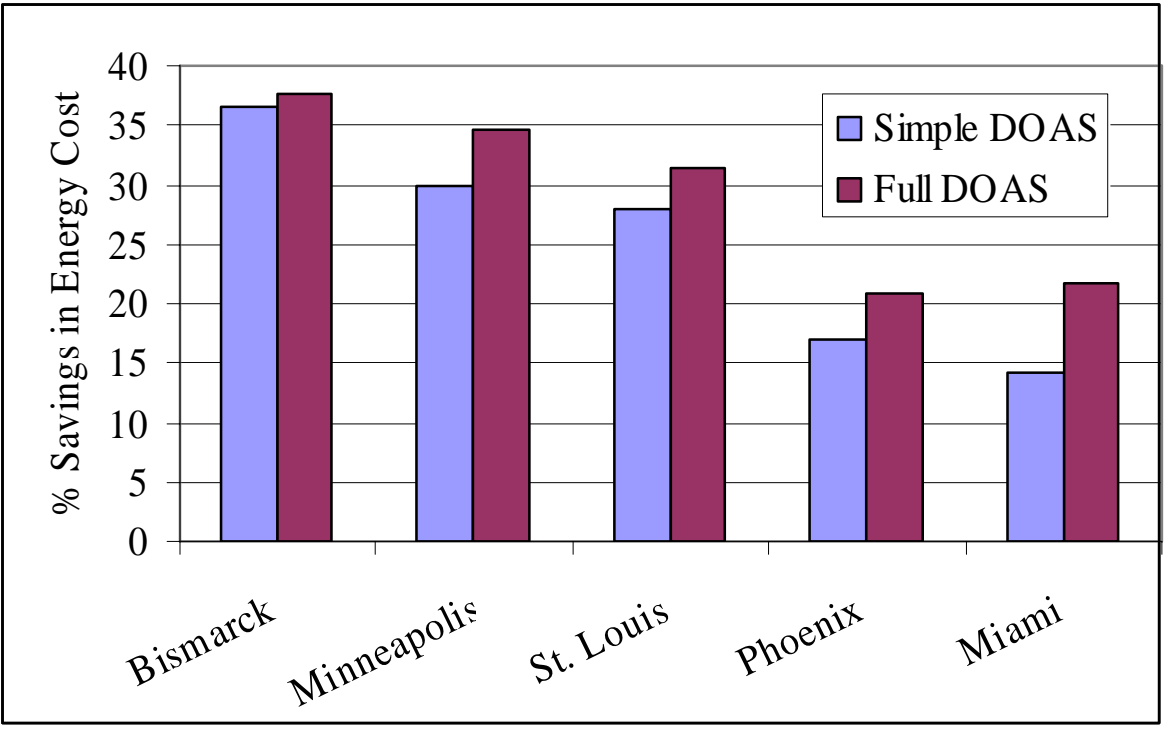

Figure 6 Savings in Annual Energy Costs Relative to Baseline WSHP system 


\subsection{Summary}

The modeled DOAS shows promise in reducing the energy consumption of the WSHP system in the office buildings in all of the climates studied. The more complex DOAS did not show significant improvement over a simple DOAS consisting of only a preheat coil and enthalpy wheel, except in Miami. The more complex DOAS was intended to meet the entire latent load of the space allowing the sensible load to be met with a radiant system. Using a radiant system may increase the savings enough to justify the added cost of the more complex DOAS system as described in the literature (Jeong et al. 2003). The more complex DOAS system modeling still showed latent cooling being provided by the WSHPs in the zones. While this does not mean that the radiant system would not provide adequate comfort to the occupants without surface condensation, further study of this issue is needed.

Although the potential for improved humidity control is cited in the literature as a significant benefit of DOAS, there is still a need for further simulation and field study of the humidity control performance of DOAS in typical U.S. commercial buildings. Mumma (2001b) analyzes the humidity impact with the assumption that the DOAS can effectively pressurize a building and prevent infiltration despite the fact that nearly all of the outdoor air supplied is being exhausted through the heat recovery subsystem. This may be possible with a very tight building envelope, but field studies by NIST and others have shown that typical U.S. commercial buildings are quite leaky (Persily 1998). Additionally, the possible presence of moisture sources in the building zones needs to be considered.

As with the DV systems, additional field study of DOAS performance is likely needed before widespread application occurs. Such studies should consider first costs, energy performance, humidity control and IAQ. Only one field study, which described the application of DOAS in Florida schools, was found in the review.

Overall, this review identified fewer research needs for DOAS than for the DV systems studied earlier and, therefore, they seem to be closer to widespread application. Their potential improved humidity control performance merits their consideration for application in building-climate combinations where the humidity load due to ventilation is a difficult design issue. 


\section{RECOMMENDATIONS}

Based on the literature review and simulation study, this project has identified several recommendations that will further the goal of realizing the potential energy efficiency and IAQ benefits of advanced ventilation systems in U.S. commercial buildings.

\subsection{Research}

- Evaluate the adequacy of humidity control capabilities of DV and DOAS systems for typical commercial building types in U.S. climates through modeling and laboratory studies.

- Conduct field studies to evaluate the performance of DV and DOAS in a variety of U.S. commercial buildings and climates. Such studies should evaluate the system performance on a whole building scale (i.e., including consideration of the building envelope) with an emphasis on addressing the potential concerns discussed in this report, in addition to demonstration of energy and comfort performance and a comparison of first cost to conventional systems.

- Conduct a detailed energy simulation study of the performance of DV systems in U.S. commercial buildings with an appropriate advanced simulation tool considering Standard 62.1 ventilation rate requirements.

- Extend evaluation to include other advanced ventilation technologies and strategies such as task ventilation, underfloor air distribution, hybrid ventilation, and demand controlled ventilation.

\subsection{Technology Transfer}

- Extend simulation capabilities of the EPA IHAT and EFAST tools to include DOAS in combination with various zone sensible thermal control systems.

- Conduct case studies of DV and DOAS in a building in hot and humid U.S. climates including evaluation of ASHRAE and other design procedures, comparison of first costs, commissioning of systems, and post-occupancy analysis of energy, thermal comfort, IAQ and humidity performance. 


\section{REFERENCES}

ASHRAE.2004. Ventilation for Acceptable Indoor Air Quality. ASHRAE Standard 62.1; American Society of Heating, Refrigerating and Air-Conditioning Engineers, Inc.

ASHRAE.2001. Energy Standard for Buildings Except Low-Rise Residential Buildings. ASHRAE Standard 90.1; American Society of Heating, Refrigerating and Air-Conditioning Engineers, Inc.

Bauman, F.S. 2003. Underfloor Air Distribution (UFAD) Design Guide, American Society of Heating, Refrigerating and Air-Conditioning Engineers, Inc.

Bjorn, H. and P.V. Nielsen. 1996. “Personal Exposure in Displacement Ventilated Rooms” Indoor Air Vol. 6: 157-167.

Bjorn, E. and P.V. Nielsen. 2002. "Dispersal of exhaled air and personal exposure in displacement ventilation rooms” Indoor Air 12: 147-164.

Brohus, H. 2003. "Relative influence of boundary conditions on the indoor air quality of a displacement ventilation room.” Proceedings of Healthy Buildings 2003.

Bourassa, N., Haves, P., and J. Huang. 2002. A Computer Simulation Appraisal of Nonresidential Low Energy Cooling Systems in California. Proceedings of ACEEE 2002 Summer Study on Energy Efficiency in Buildings.

Building Systems Laboratory. 1999. BLAST 3.0 Users Manual. Urbana-Champaign, Illinois: Building Systems Laboratory, Department of Mechanical and Industrial Engineering, University of Illinois.

Clayton, C.A., Wallace, L.A., Ozkaynak, H., and J.D. Spengler. 1993. "Particle total exposure assessment methodology (PTEAM) study: distributions of aerosol and elemental samples in a southern California community," Journal of Exposure Analysis and Environmental Epidemiology 6: $227-250$.

Coad, W. 1999. “Conditioning Ventilation Air for Improved Performance and Air Quality.” HPAC Engineering: September 1999.

CEC. 2003. Low Energy Systems Appraisals. California Energy Commission Technical Report 50003-097-A7.

Chen, Q. and L. Glicksman. 2003. System Performance Evaluation Design Guidelines for Displacement Ventilation. ASHRAE.

Chen, Q. and L. Glicksman. 1999. Performance Evaluation and Development of Design Guidelines for Displacement Ventilation - Final Report on ASHRAE Research Project RP-949. ASHRAE.

Dols, W.S. and G.W. Walton. 2002. CONTAMW 2.0 User Manual, NISTIR 6921.

Ferro, A.R., Kopperud, R.J., and L.M. Hildemann. 2004. "Elevated personal exposure to particulate matter from human activities in a residence," Journal of Exposure Analysis and Environmental Epidemiology 14: S34 - S40.

Fischer, J.C. and C.W. Bayer. 2003. “Report Card on Humidity Control.” ASHRAE Journal May 2003.

Gatley, D. P. 2000a. "Dehumidification Enhancements for 100-Percent-Outside-Air AHUs. Part 1 of 3” HPAC Heating/Piping/Air Conditioning Engineering: September 2000. 
Gatley, D. P. 2000b. “Dehumidication Enhancements for 100-Percent-Outside-Air AHUs. Part 2 of 3” HPAC Heating/Piping/Air Conditioning Engineering: October 2000.

Gatley, D. P. 2000c. "Dehumidication Enhancements for 100-Percent-Outside-Air AHUs. Part 3 of 3” HPAC Heating/Piping/Air Conditioning Engineering: November 2000.

Holland, D. and A. Livchak. 2002. Improving Indoor Air Quality in Schools by Utilizing Displacement Ventilation System. Proceedings of Indoor Air 2002.

Howe, M., Holland, D., and A. Livchak. 2003. Displacement Ventilation - Smart Way to Deal with Increased Heat Gains in the Telecommunication Equipment Room. Proceedings of 2003 ASHRAE Winter Meeting.

Jeong, J., S.A. Mumma and W.P. Bahnfleth Jr. 2003. "Energy Conservation Benefits of a Dedicated Outdoor Air System with Parallel Sensible Cooling by Ceiling Radiant Panels.” ASHRAE Transactions 2003.

Khattar, M., Shirey III, d., and R. Raustad. 2003. “Cool \& Dry: Dual-Path Approach for a Florida School.” ASHRAE Journal May 2003.

Khattar, M. K. and M. J. Brandemuehl. 1996. “Systems for preconditioning ventilation air.” Proceedings of Indoor Air '96.

Khattar, M. K. and M. J. Brandemuehl. 2002. "Separating the V in HVAC: A Dual-Path Approach.” ASHRAE Journal May 2002.

Klein S. 2000 TRNSYS - A Transient System Simulation Program Engineering Experiment Station Report 38-13. Solar Energy Laboratory, University of Wisconsin - Madison.

Kosonen, R. 2002. "Displacement ventilation for room air moisture control in hot and humid climate.” Proceedings of Roomvent 2002.

Li, Y., Sandberg, M., and S. Hui. 2004. "Robustness of air distribution in plenum-based ductless ventilation systems” International Journal of Ventilation 3:105-118.

Livchak, A. and D. Nall. 2000. “Displacement Ventilation - Application for Hot and Humid Climate” Proceedings of Clima 2000.

Marion,W. and K. Urban. 1995. User’s Manual for TMY2s. National Renewable Energy Laboratory.

Matsumoto, H., Matsusaki, A., and B. Ohba. 2004. “CFD Simulation of Air Distribution in Displacement Ventilated Rooms with a Moving Object.” Proceedings of Roomvent 2004.

Mattsson, M., Smedje, G., Holmquist, L., Vesterberg, O., and R. Walinder. 2003. Mixing and displacement ventilation compared in classrooms; distribution of particles, cat allergen, and $\mathrm{CO}_{2}$. Proceedings of Healthy Buildings 2003.

McDonell, G. 2003. “Underfloor \& Displacement - Why They’re Not the Same” ASHRAE Journal July 2003.

McDowell, T., Emmerich, S., Thornton, J., and G. Walton. 2003. “Integration of Airflow and Energy Simulation Using CONTAM and TRNSYS.” ASHRAE Transactions 2003.

Melikov, A., Pitchurov, G., Naydenov, K. and G. Langilde. 2005. "Field study on occupant comfort and the office thermal environment in rooms with displacement ventilation.” Indoor Air Vol. 15, No. 3.

Morris, W. 2003 “The ABC’s of DOAS dedicated Outdoor Air Systems” ASHRAE Journal May 2003. 
Mumma, S.A. 2001a. “Designing Dedicated Outdoor Air Systems.” ASHRAE Journal: May 2001. Mumma, S.A. 2001b. “Ceiling Panel Cooling Systems.” ASHRAE Journal: November 2001. Mumma, S.A. and K.M. Shank. 2001. "Achieving Dry Outside Air in an Energy-Efficient Manner." ASHRAE Transactions, Vol. 107 Pt. 1.

Nielsen, P.V., Larsen, T.S., and C. Topp. 2003. "Design methods for air distribution systems and comparison between mixing ventilation and displacement ventilation.” Proceedings of Healthy Buildings 2003.

Novoselac, A. and J. Srebric. 2002a. “A critical review on the performance and design of combined cooled ceiling and displacement ventilation systems” Energy and Buildings 34:497-509.

Novoselac, A. and J. Srebric. 2002b. Influence of Different Pollutant Sources on Selection of Ventilation System in Rooms with Cooled Ceilings. Proceedings of Indoor Air 2002.

Persily AK. 1998. “Airtightness of Commercial and Institutional Buildings” Proceedings of ASHRAE Thermal Envelopes VII Conference.

Roth, K.W., Westphalen, D., Dieckmann, J., Hamilton, S.D., and W. Goetzler. 2002. Energy Consumption Characteristics of Commercial Building HVAC Systems Volume III: Energy Savings Potential. TIAX Report No. 68370-00 for DOE Building Technologies Program.

Seppanen, O.A., Fisk, W.J., Eto, J., and D.T. Grimsrud. 1989. “Comparison of Conventional Mixing and Displacement Air-Conditioning and Ventilating Systems in U.S. Commercial Buildings.” ASHRAE Transactions 1989.

Shank, K.M. and S.A. Mumma. 2001. "Selecting the Supply Air Conditions for a Dedicated Outdoor Air System Working in Parallel with Distributed Sensible Cooling Terminal Equipment.” ASHRAE Transactions 2001.

Thatcher, T.L. and D.W. Layton. 1995. "Deposition, resuspension, and penetration of particles within a residence," Atmospheric Environment, 29(13), 1487 - 1497.

Xie, Y.H., Cheong, K.W.D., Kosonen, R., Yu, W.J., and H.C. Leow. 2003. Indoor air quality on displacement ventilation in the tropics - a chamber study. Proceedings of Healthy Buildings 2003.

Zhao, B., Zhang, Z., Li, X., and D. Huant. 2004. Comparison of Diffusion Characteristics of Aerosol Particles in Different Ventilated Rooms by Numerical Method. Proceedings of 2004 ASHRAE Winter Meeting.

Zhang, Z. and Q. Chen. 2004. "Numerical analysis of particle behaviors in indoor air using Lagrangian method.” Proceedings of Roomvent 2004.

Zhivov, A.M., and A.A. Rymkevich. 1998. "Comparison of Heating and Cooling Energy Consumption by HVAC System with Mixing and Displacement Air Distribution for a Restaurant Dining Area in Different Climates.” ASHRAE Transactions, Vol. 104 Part 2. 